\title{
Requirements for a Hydrogen Powered All-Electric Manned Helicopter
}

\author{
Anubhav Datta* \\ Wayne Johnson ${ }^{\dagger}$ \\ NASA Ames Research Center, Moffett Field, CA, 94035, U.S.A.
}

The objective of this paper is to set propulsion system targets for an all-electric manned helicopter of ultra-light utility class to achieve performance comparable to combustion engines. The approach is to begin with a current two-seat helicopter (Robinson R 22 Beta II-like), design an all-electric power plant as replacement for its existing piston engine, and study performance of the new all-electric aircraft. The new power plant consists of highpressure Proton Exchange Membrane fuel cells, hydrogen stored in 700 bar type-4 tanks, lithium-ion batteries, and an AC synchronous permanent magnet motor. The aircraft and the transmission are assumed to remain the same. The paper surveys the state of the art in each of these areas, synthesizes a power plant using best available technologies in each, examines the performance achievable by such a power plant, identifies key barriers, and sets future technology targets to achieve performance at par with current internal combustion engines.

\section{Nomenclature}

$\begin{array}{ll}A & \text { Stack area, } \mathrm{cm}^{2} \\ E_{h}, E_{r} & \text { Ideal and practical reversible cell voltages, } \mathrm{V} \\ F & \text { Faraday constant, Coulomb/mole } \\ I, I_{D} & \text { Current, design current, A } \\ L_{S} & \text { Stack volume, L } \\ P, P_{D}, P_{\text {max }} & \text { Power, design power, maximum power, } \mathrm{kW} \\ \dot{Q} & \text { Heating rate, } \mathrm{kW} \\ Q & \text { Motor torque, Nm } \\ S_{H} S_{O} & \text { Hydrogen and oxygen stoichiometries } \\ W_{S} & \text { Stack weight, kg } \\ V & \text { Voltage, V } \\ V_{b r}, V_{b e} & \text { Speeds for best range and best endurance, } \mathrm{km} / \mathrm{hr} \\ i, i_{c} & \text { Fuel cell current densities (nominal, design), A } / \mathrm{cm}^{2} \\ k & \text { Battery Peukart coefficient } \\ m_{H / O / A} & \text { Molecular masses of hydrogen, oxygen, and Air, } \mathrm{kg} / \mathrm{mole} \\ \dot{m}_{H, S}, \dot{m}_{O, S}, \dot{m}_{A, S} & \text { Supply rates of hydrogen, oxygen, and Air, mole } / \mathrm{s} \\ \dot{w}_{H, S}, \dot{w}_{O, S}, \dot{w}_{A, S} & \text { Supply rates of hydrogen, oxygen, and Air, } \mathrm{kg} / \mathrm{s} \\ n_{c} & \text { Number of cells } \\ p, p_{c}, p_{\max } & \text { Fuel cell power densities (nominal, design, maximum), W/ } / \mathrm{cm}^{2} \\ r & \text { Battery internal resistance, Ohms } \\ t_{c} & \text { Fuel cell effective thickness, cm } \\ v, v_{c} & \text { Fuel cell voltages (nominal, design), V } \\ x & \text { Battery depth of discharge fraction } \\ x_{O} & \text { Mole fraction of oxygen in dry air } \\ \end{array}$

* Rotorcraft Dynamicist, STC, U.S.Army Aeroflightdynamics Directorate, Senior Member AIAA.

$\dagger$ †eromechanics branch, NASA Ames Research Center, Fellow AIAA. 


$\begin{array}{ll}\eta_{f}, \eta_{H}, \eta_{M} & \text { Efficiencies; stack, fuel, and motor } \\ \rho & \text { Hydrogen density, } \mathrm{kg} / \mathrm{L} \\ \rho_{c} & \text { Fuel cell effective density, } \mathrm{kg} / \mathrm{m}^{3} \\ \xi & \text { Fuel cell porosity fraction } \\ \lambda_{H}, \lambda_{A} & \text { Effective stoichiometries of hydrogen and air }\end{array}$

\section{Introduction}

The objective of this paper is to set propulsion system targets for an all-electric manned helicopter of ultra-light utility class to achieve performance comparable to combustion engines. To this end, the paper explores a fundamental transformation of a rotorcraft propulsion system - including fuel, storage, engine, and transmission. The approach is to begin with an ultra-light utility helicopter model as baseline (Robinson R22 Beta II-like), replace its existing piston engine with an all-electric power plant model, and carry out detailed performance studies on the new aircraft. This research is part of the vision for environmentally sustainable green aviation that will dramatically reduce fuel consumption, cut pollutants and green-house gas emissions, eliminate dependency on hydrocarbon based fuels, and contribute to the global-energy related carbon dioxide target of $50 \%$ below current by year 2050. The requirements of hover and low speed flight make rotorcraft targets unique and more stringent - in specific power, specific torque, and transmission than automobiles, submarines, or fixed-wing aircraft. The purpose of this paper is to quantify these targets.

Elimination of hydrocarbon based fuels requires a complete overhaul of all energy flow segments: production, transfer, storage, and extraction. Today, in aviation, extraction is based on internal combustion (IC) engines, storage on hydrocarbon fuels, transfer by pipelines and transportation chains and production on crude oil. The aim of the new system is extraction based on electric motor and fuel cells, storage based on batteries and hydrogen, transfer by grid and hydrogen infrastructure, and production from sustainable sources. The segments of sustainable production and transfer are already being addressed in the context of commercially viable electric vehicles (EV) and plug-in hybrid electric vehicles (PHEV). ${ }^{1}$ The on-going U.S. Department of Energy (DoE) Hydrogen Program (DoE HP) ${ }^{2}$ is focused on achieving specific hydrogen and fuel cell technology targets for light utility automobiles by year 2015. The focus of this paper is on aviation, and in particular, rotorcraft.

Hybrid electric vehicles (HEVs) like the Toyota Prius and Honda Insight use NiMH batteries with typical characteristics of $0.2 \mathrm{~kW} / \mathrm{kg}$ of specific power, $65 \mathrm{Wh} / \mathrm{kg}$ of specific energy, and $150 \mathrm{Wh} / \mathrm{L}$ of energy density, but limited energy capacities of only $2-5 \mathrm{kWh}$. Electric vehicles (EVs), driven by batteries, are now becoming commercially available with increasing energy capacities e.g. the Chevrolet Volt $(16 \mathrm{kWh})$, Ford Focus $(23$ $\mathrm{kWh})$ and Nissan Leaf $(24 \mathrm{kWh})$. EVs, driven by fuel cells, are also making their debut with increasing power ratings, e.g. the Audi Q5 $(93 \mathrm{~kW})$, the Honda Clarity $2009(100 \mathrm{~kW})$, the the Mercedes F125 $(172 \mathrm{~kW})$. Their specific energy and power still fall far short for purposes of rotorcraft with capabilities comparable to combustion engines but begin to make a case for their detailed assessment. The intent of this paper is to carry out such an assessment.

In fixed-wing aviation, a manned, all-electric battery fuel cell-hybrid aircraft was flown successfully by Boeing by converting a two-seat Austrian HK36 motor glider of $700 \mathrm{~kg}$ gross take off weight (GTOW). ${ }^{3,4}$ The power requirement in fixed-wing gliders are low, ranging from 10-60 kW. In rotary-wing aviation, inventors have recently begun demonstrating manned all-electric battery rotorcraft over the last two years. ${ }^{8,9}$ While innovative, these are focused more on low power exotic bare-bones airframes rather than high power breakthrough electric propulsion of practical relevance. An effort to demonstrate an all-electric battery helicopter of practical relevance is currently underway in Sikorsky using a S-300C helicopter of $930 \mathrm{~kg}$ GTOW as baseline for conversion. A major challenge for a battery-only power plant is its anticipated low endurance of around 15 min.

The propulsion system explored in this paper is fuel cell based and motivated by the Honda Clarity automobile ${ }^{10}$ and the Boeing airplane. ${ }^{3,4}$ It consists of a combination of Proton Exchange Membrane Fuel Cells (PEMFC) and lithium-ion batteries in an attempt to use the advantages of each - high specific energy of hydrogen to extend range and high specific power of lithium-ion batteries to improve hover ceiling. This is precisely the combination used by the Boeing fuel cell airplane. The objective here is to study its performance on a rotary-wing aircraft with high power, high torque, hover and low-speed missions. The study is based on an ultra-light utility helicopter of practical scale, similar to a two-seat Robinson R 22 Beta II. The R 22 
is the world's largest selling light-utility helicopter - the counterpart of Cessna 172 in the fixed-wing world.

The paper is organized as follows. Following introduction, Section II summarizes the baseline aircraft and its analysis. Section III describes the preliminary design of the five major components of the new all-electric power plant, including a survey of current state of the art in each. Section IV synthesizes three types of power plants - battery-only (B-only), fuel cell-only (FC-only), and battery fuel cell-hybrid (BFC-hybrid) - using the building blocks described in Section III. These power plants are then sized and characterized in terms of engine performance for conversion of the original aircraft. Section V studies the performance of the converted all-electric aircraft. Three benchmark missions are proposed for mission analysis. Section VI summarizes the current state of technology relative piston engines. Based on this summary and the preliminary design and survey carried out in Section III, future technology targets are set. Section VII ends the paper with three key conclusions from this work.

\section{The Baseline Helicopter}

The two-seat Robinson R22 Beta II helicopter (Fig. 1) is considered as baseline. The relevant specifications available in public domain are as follows. They are assumed to be at Sea Level/International Standard Atmosphere (SL/ISA, i.e., 1 atm, $59 \mathrm{~F}$ or $15^{\circ} \mathrm{C}$ ).

Aircraft: maximum gross take off weight $(\mathrm{GTOW})=622 \mathrm{~kg}$; empty weight $=388 \mathrm{~kg}$; maximum payload $(\mathrm{PL})=2$ people + baggage $=181 \mathrm{~kg}$ (standard) and $153 \mathrm{~kg}$ (with auxiliary tank); rotor speed $=510$ revolutions per minute $(\mathrm{RPM})$; cruise speed (at $70 \%$ power $)=177 \mathrm{kmph}$; economical cruise speed $=153$ $\mathrm{kmph}$; endurance (at $65 \%$ power) $=3 \mathrm{hr} 20$ min (but corresponding PL unknown); range $=333 \mathrm{~km}$ (standard) and $555 \mathrm{~km}$ (with auxiliary tank).

Engine: one Lycoming O-360-J2A engine; maximum derated power $=97.5 \mathrm{~kW}$ (transmission limit); continuous operating power $=93 \mathrm{~kW}$ (at maximum speed); cruise power (assumed $70 \%$ of derated) $=68.25$ $\mathrm{kW}$; endurance power (assumed $65 \%$ of derated) $=63.4 \mathrm{~kW}$; engine speed $=2652 \mathrm{RPM}$; weight $($ dry $)=117$ $\mathrm{kg}$; volume $=362 \mathrm{~L}$.

Fuel: maximum fuel weight $=52 \mathrm{~kg}$ (standard) $+29 \mathrm{~kg}$ (auxiliary) $=81 \mathrm{~kg}$; fuel volume $=72.5 \mathrm{~L}$ (standard) $+39.75 \mathrm{~L}$ (auxiliary) $=112.25 \mathrm{~L}$; tank weight unknown, $5 \%$ fuel weight (assumed) $=2.6 \mathrm{~kg}$ (standard) $+1.45 \mathrm{~kg}$ (auxiliary) $=4.05 \mathrm{~kg}$; tank volume assumed same as fuel volume.

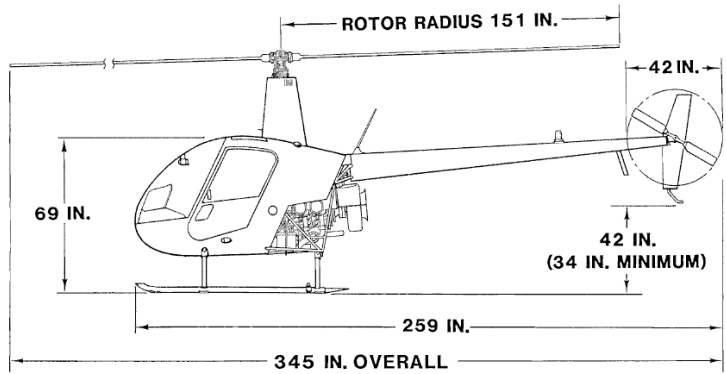

Figure 1. The two-seat Robinson R22 Beta II helicopter.

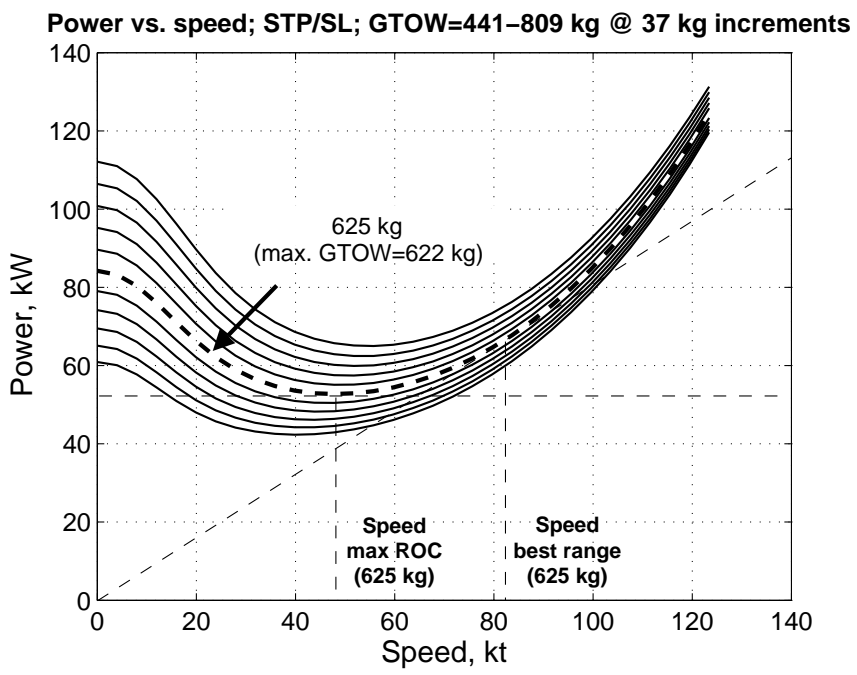

Figure 2. Predicted power vs. speed at SL/ISA for gross take off weights (GTOW) from 441-809 $\mathrm{kg}$ with $37 \mathrm{~kg}$ increments.

The power required to fly the aircraft is predicted based on standard analysis procedures ${ }^{5}$ carried out using the University of Maryland Advanced Rotorcraft Code ${ }^{6}$ using simple models (in absence of detailed rotor and fuselage data) modified appropriately with guidance from the pilot's operating handbook ${ }^{7}$ to reproduce gross performance characteristics given above. The model considers rigid blade structures (flap and torsion only), blade element aerodynamics (2-dimensional airfoil tables, quasi-steady aerodynamics, and uniform inflow), and propulsive trim with look-up table based aircraft properties. For example, Fig. 2 shows 
typical aircraft power predictions for varying GTOW under SL/ISA. There is no data available for validation, instead, airfoil zero angle drag and fuselage drag are set appropriately to reproduce hover power and forward flight best range speed $\left(V_{b r}\right)$.

\section{Design of an All-Electric Power Plant}

The electric power plant consists of five major components: the Proton Exchange Membrane Fuel Cell (PEMFC) system, a compressor-expander (C-E), hydrogen storage, lithium-ion batteries, and the electric motor and transmission. The preliminary design of these components are described below with emphases on the available state of the art in each and challenges related to the present application.

\section{III.A. The PEMFC system}

The preliminary design of the PEMFC system follows textbook procedures. ${ }^{11-13}$ PEMFC has the highest specific power of all fuel cells today and is therefore considered the basis for the present design. A fuel cell system includes the stack, balance-of-plant (BOP), fuel system, and power electronics. The BOP includes air, thermal, and water management systems. Out of all BOP components, the compressor-expander (C-E) of the air management system is particularly important for altitude losses and hence considered in detail.

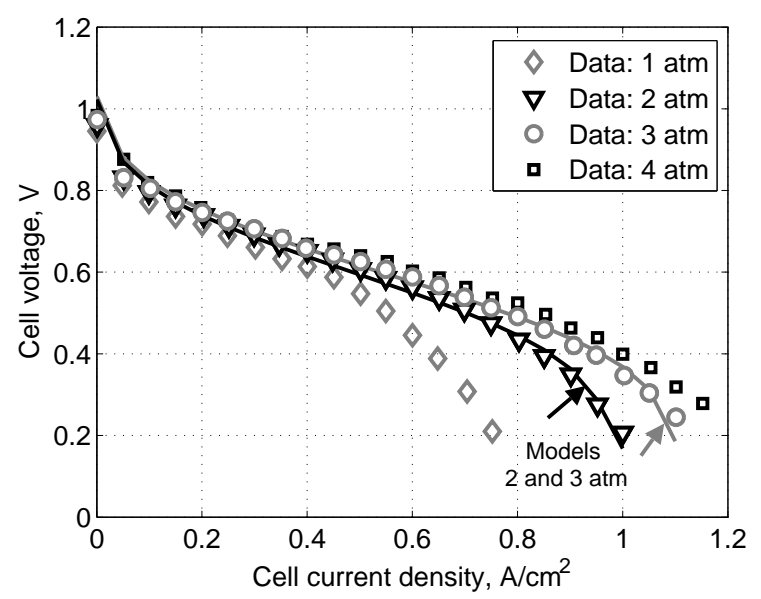

Figure 3. Typical current density-voltage $(i-v)$ characteristics of a single PEMFC fuel cell; $25 \mathrm{~cm}^{2}$ area, $\mathrm{Pt} / \mathrm{C}, 0.4 \mathrm{mg} / \mathrm{cm}^{2} \mathrm{Pt}$ loading, Nafion 112,115,117 MEA; $H_{2} /$ Air stoichiometry $=1.2 / 2$; anode and cathode humidity $100 \% ; 80^{\circ} \mathrm{C}$; from Ref. 14 .

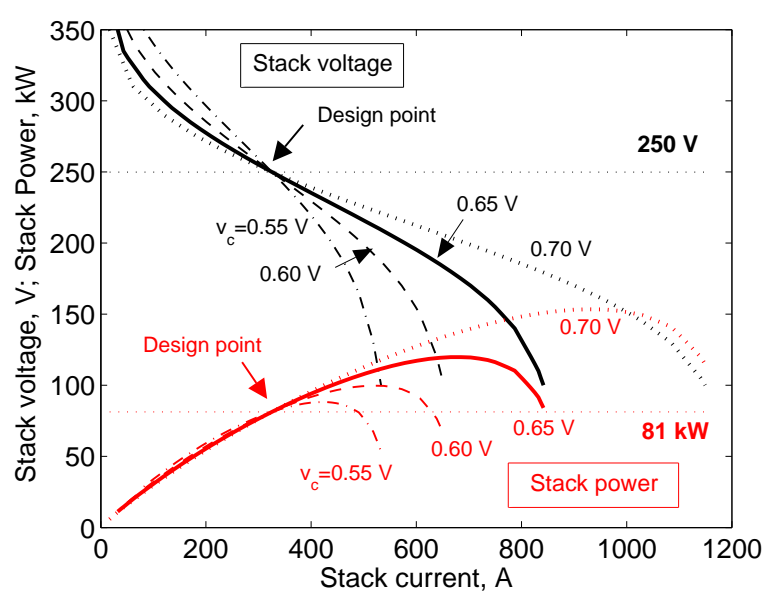

Figure 5. Stack voltage and power vs. current; rated power $81 \mathrm{~kW}$, voltage $250 \mathrm{~V}$.

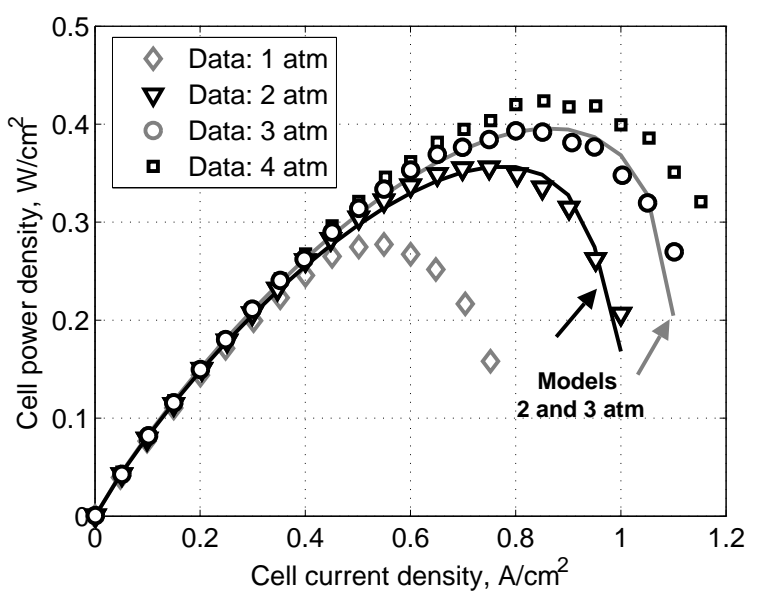

Figure 4. Corresponding power density-voltage ( $p$ $v$ ) characteristics of a single PEMFC fuel cell; 25 $\mathrm{cm}^{2}$ area, $\mathrm{Pt} / \mathrm{C}, 0.4 \mathrm{mg} / \mathrm{cm}^{2} \mathrm{Pt}$ loading, Nafion 112,115,117 MEA; $H_{2} /$ Air stoichiometry=1.2/2; anode and cathode humidity $100 \% ; 80^{\circ} \mathrm{C}$; from Ref. 14 .

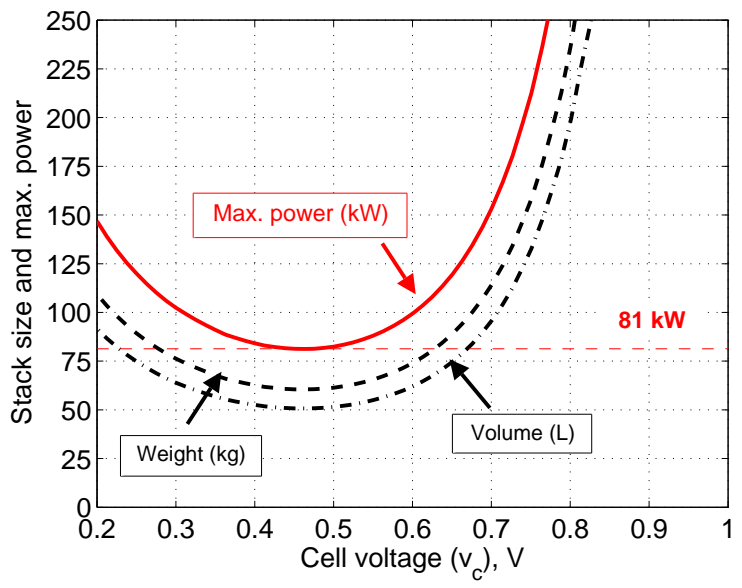

Figure 6. Stack size (weight and volume) and maximum power vs. choice of design operating cell voltage $v_{c} ;$ rated power $81 \mathrm{~kW}$. 


\section{III.A.1. Stacks}

The typical current-voltage $(i-v)$ characteristics of a PEMFC are shown in Fig. 3 (data from Ref. 14). The corresponding power-voltage $(p-v$, where $p=i v)$ characteristics are shown in Fig. 4 . Operations at 2 to $3 \mathrm{~atm}$ are considered for the current design. Static models are fit to the data ${ }^{13}$ for smooth variations during design trade studies. High voltage operation (left side of curves) minimizes fuel weight, low voltage operation (right side of curves) minimizes stack weight. For a required power output $P_{D}$ at a voltage $V_{D}$, the choice of the design (or rated) cell voltage $v_{c}$ sizes the stack. Then, the number of cells in the stack must equal $n_{c}=V_{D} / v_{c}$. The rated cell current density $i_{c}$ and power density $p_{c}=i_{c} v_{c}$ are then determined by the characteristic curves. The rated current drawn from the stack is $I_{D}=P_{D} / V_{D}=P_{D} /\left(n_{c} v_{c}\right)$. The stack active area is then given by $A=I_{D} / i_{c}=P_{D} /\left(n_{c} v_{c} i_{c}\right)=P_{D} /\left(n_{c} p_{c}\right)$. Once the stack design conditions are set (i.e. $n_{c}$ and $A$ set to produce $P_{D}$ at $V_{D}$ at an operating $v_{c}$ ) the output current, voltage, and power are set by controlling the cell current $i$.

$$
I=A i ; \quad V=n_{c} v ; \quad P=V I=A n_{c} p
$$

where $v$ and $p$ are obtained corresponding to $i$ from the characteristic curves. The cell current $i$ is controlled by varying the fuel flow rate. The maximum power available from the stack is $P_{\max }=A n_{c} p_{\max }$ where $p_{\max }$ is the maximum cell power density. The stack efficiency $\eta_{f}=v / E_{h}$ where $E_{h}=1.472 \mathrm{~V}$ is the ideal reversible cell voltage corresponding to the enthalpy of formation (heating value) of the reaction $\mathrm{H}_{2}+(1 / 2) \mathrm{O}_{2} \rightarrow \mathrm{H}_{2} \mathrm{O}(l)$ at $80^{\circ} \mathrm{C}$, pure reactants at $1 \mathrm{~atm}$, and product water in liquid form (i.e. higher heating value). Note that the practical reversible cell voltages $E_{r}$ using impure reactants (air, instead of oxygen) and operating at pressures of 2 and $3 \mathrm{~atm}$ are $1.180 \mathrm{~V}$ and $1.176 \mathrm{~V}$ respectively but are not used for quoting efficiencies. The practical irreversible cell voltage is $v$ which varies as per the $i-v$ plots shown earlier.

\begin{tabular}{lcccc}
\hline Parameters & S2.98 & S2.68 & S3.98 & S3.68 \\
\hline \hline Pressure (atm) & 2 & 2 & 3 & 3 \\
P rated (kW) & 81.33 & 56.30 & 93.25 & 64.55 \\
P net (kWe) & 69.2 & 47.9 & 72.7 & 50.3 \\
net \% useful & 85.1 & 85.1 & 78.0 & 78.0 \\
P max net (kWe) & 97.5 & 67.5 & 97.5 & 67.5 \\
max net \% useful & 81.4 & 81.4 & 71.2 & 71.2 \\
No. cells & 384 & 384 & 384 & 384 \\
A $\left(\mathrm{cm}^{2}\right)$ & 875 & 606 & 901 & 624 \\
$v_{c}(\mathrm{~V})$ & 0.651 & 0.651 & 0.651 & 0.651 \\
$i_{c}\left(\mathrm{~A} / \mathrm{cm}^{2}\right)$ & 0.372 & 0.372 & 0.414 & 0.414 \\
$I_{D}(\mathrm{~A})$ & 325 & 225 & 373 & 258 \\
$V_{D}(\mathrm{~V})$ & 250 & 250 & 250 & 250 \\
$\eta_{f}$ & 0.44 & 0.44 & 0.44 & 0.44 \\
$\dot{Q}(\mathrm{~kW})$ & 102.8 & 71.1 & 117.7 & 81.5 \\
& & & & \\
$W_{S}(\mathrm{~kg})$ & 89.15 & 61.71 & 91.81 & 63.56 \\
$L_{S}(\mathrm{~L})$ & 74.74 & 51.74 & 76.97 & 53.28 \\
\hline
\end{tabular}

Table 1. Four stack designs, two each at 2 and $3 \mathrm{~atm}$, one for high power $(97.5 \mathrm{kWe})$ and one for low power (67.5 kWe), all with temperature $80^{\circ} \mathrm{C}$ and hydrogen/air stoi $1 / 2.5$; stack voltage $250 \mathrm{~V}$, operations corresponding to SL/ISA.

Consider a stack designed to deliver $P_{D}=81.33 \mathrm{~kW}$ at voltage $V_{D}=250 \mathrm{~V}$. Let the operating pressure be $2 \mathrm{~atm}$. (The maximum net power from such a stack equals the maximum power required by the helicopter, as shown later.) Depending on the choice of $v_{c}$ the resulting stack will have one of the operating characteristics shown in Fig. 5. The plot shows the gross power from the stacks. A part of this power will be used for the compressor required to achieve the high operating pressure. Compression to $3 \mathrm{~atm}$ obviously takes more power than to $2 \mathrm{~atm}$ particularly due to the additional pressure loss with altitude. Thus a $2 \mathrm{~atm}$ operation provides a greater percentage of gross power as net power (net \% useful) or effective power (kWe). It also implies a smaller compressor. An estimate of the stack volume and weight is made using

$$
\begin{aligned}
L_{S}=n_{c} A t_{c}=\frac{P_{D}}{p_{c}} t_{c} & =\frac{P_{\max }}{p_{c, \max }} t_{c} ; \quad W_{S}=L_{S} \rho_{c} \xi \\
5 & \text { of } 28
\end{aligned}
$$


where $t_{c}$ is the average thickness of an individual cell unit including the membrane-electrode-assembly (MEA), catalysts, and flow structure, $\rho_{c}$ is the average density of the individual cell unit and $\xi$ is its porosity $\approx 0.6$. Thus, the stack is sized only by the power output and the cell power density. The output voltage determines only the configuration of stack (number of cells $n_{c}$ and active area $A$ ) but not the weight or volume. An estimate of the material properties $\left(t_{c}\right.$ and $\left.\rho_{c}\right)$ is made using Honda Clarity 2009 fuel cell car data: ${ }^{10}$ $P_{\max }=100 \mathrm{~kW}, L_{S}=57 \mathrm{~L}$ (power density $1.75 \mathrm{~kW} / \mathrm{L}$ ) and $W_{S}=68 \mathrm{~kg}$ (specific power $1.47 \mathrm{~kW} / \mathrm{kg}$ ). The stack operating characteristics are not known, so for conservative estimates it is assumed to behave as the 3 atm characteristics (higher than $3 \mathrm{~atm}$ is unlikely). Thus, $p_{\max }$ is obtained from the $3 \mathrm{~atm} i-v$ curve. Using a porosity of $\xi=0.6$ we have $t_{c}=2.224 \mathrm{~mm}$ and $\rho_{c}=1988 \mathrm{~kg} / \mathrm{m}^{3}$. Porosity is merely a scaling factor and does not affect final weights. The stack size then varies with the design cell voltage $v_{c}$ as shown in Fig. 6 .

The choice of $v_{c} \approx 0.45 \mathrm{~V}$ maximizes power density $p_{c}$ (Figs. 3 and 4 ) and produces the minimum size. The maximum power however is limited to exactly $81.33 \mathrm{~kW}$. A higher $v_{c}=0.65 \mathrm{~V}$ produces a larger stack, but also delivers a maximum power of $119.73 \mathrm{~kW}$. This margin is needed to provide BOP and other expenses. The net power, or effective power $(\mathrm{kWe})$, is gross power minus these expenses. Note that a higher $v_{c}$ also increases stack efficiency $\left(\eta_{f}=v_{c} / E_{h}\right)$, meaning less fuel and less waste heat. A cell voltage of $v_{c}=0.65$ $\mathrm{V}$ is chosen for the current design. This gives $L_{S}=74.74 \mathrm{~L}$ (energy density $1.6 \mathrm{~kW} / \mathrm{L}$ ) and $W_{S}=89.15$ $\mathrm{kg}$ (specific energy $1.34 \mathrm{~kW} / \mathrm{kg}$ ). As reference, DoE 2015 targets for power density and specific power are 2 $\mathrm{kW} / \mathrm{L}$ and $2 \mathrm{~kW} / \mathrm{kg}$ respectively for a reference stack of $80 \mathrm{kWe}$ maximum net power (gross power minus BOP expenses and other losses).

Table 1 shows four stack designs, two each for 2 and 3 atm operations, one for high and one for low power. The high and low powers correspond to maximum net powers of 97.5 and $67.5 \mathrm{kWe}$ respectively. The $97.5 \mathrm{kWe}$ stack is meant for a fuel cell-only power plant. The $67.5 \mathrm{kWe}$ stack is meant for a battery fuel cell-hybrid power plant where $30 \mathrm{~kW}$ is delivered by the battery. The BOP loss is the compressor loss. Other accessories are assumed to consume $5 \%$ of rated power.

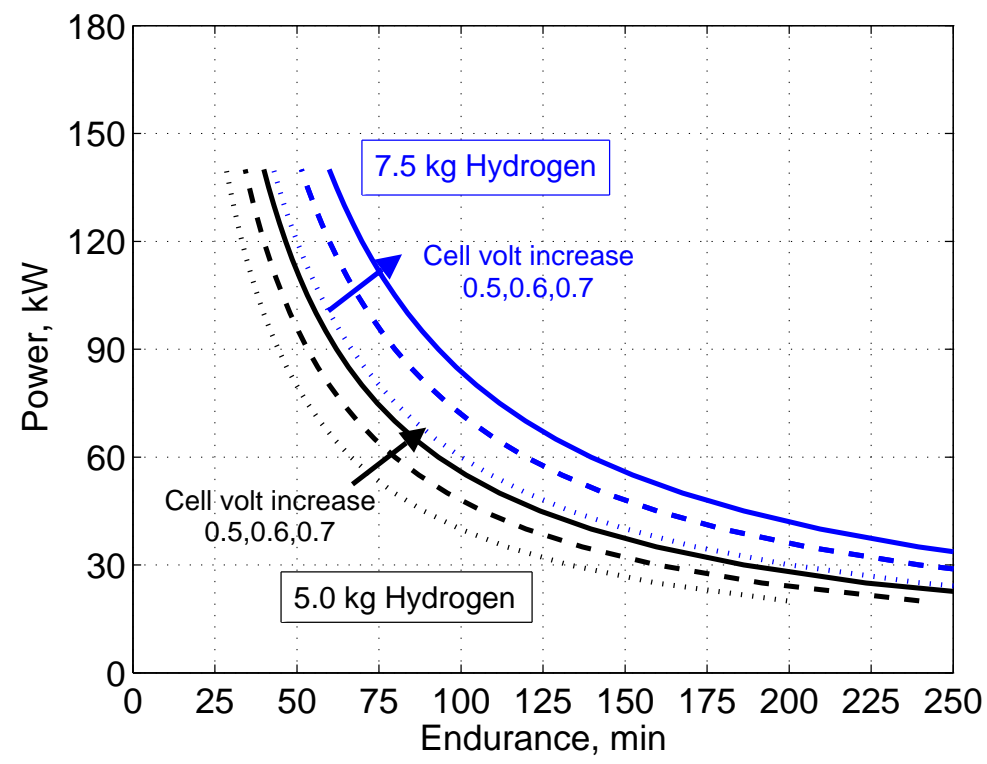

Figure 7. Power vs. hydrogen supply rate (plotted as supply time for fixed amounts, 5 and $7.5 \mathrm{~kg}$, of hydrogen) for various cell voltages.

\section{III.A.2. Fuel flow}

The electrode half reactions are

$$
\begin{array}{cl}
\mathrm{H}_{2} \rightarrow 2 \mathrm{H}^{+}+2 e^{-} & \text {Anode, release of electrons, oxidation } \\
(1 / 2) \mathrm{O}_{2}+2 e^{-}+2 \mathrm{H}^{+} \rightarrow \mathrm{H}_{2} \mathrm{O} & \text { Cathode, capture of electrons, reduction }
\end{array}
$$


From elementary chemistry, to produce a current $I$, hydrogen consumption rates must equal $\dot{m}_{H, C}$ mole/s or $\dot{w}_{H, C} \mathrm{~kg} / \mathrm{s}$ where

$$
\dot{m}_{H, C}=S_{H} \frac{1}{N F} I_{c}=S_{H} \frac{1}{N F} \frac{P}{v} ; \quad \dot{w}_{H, C}=m_{H} \dot{m}_{H, C}
$$

Here $S_{H}=1$ is hydrogen stoichiometry (see anode reaction), $N=2$ is number of electrons participating, $F=$ 96485 Coulomb/mole is Faraday constant, and $m_{H}=2.016 \times 10^{-3} \mathrm{~kg} /$ mole is the molar mass of hydrogen. Supply rate is consumption rate divided by the fuel efficiency factor $\eta_{H}$. The effective stoichiometry is then $\lambda_{H}=S_{H} / \eta_{H}$. Hydrogen is expensive, hence typically $\eta_{H} \approx 1$, i.e., $\lambda_{H} \approx S_{H}$. The hydrogen supply rate depends only on the power output and the cell voltage. Given a fixed power output and cell voltage the total time of operation is simply the amount of hydrogen available divided by the supply rate. Figure 7 shows the power versus time of operation. Increase in cell voltage increases stack efficiency and hence amount of energy extracted from hydrogen. Thus it is desirable to have as high a cell voltage as possible. This is in direct contradiction to cell voltage for minimum stack weight (Fig. 6). The oxygen consumption and the air supply rates are

$$
\dot{w}_{O, C}=S_{O} \frac{m_{O}}{N F} \frac{P}{v} ; \quad \dot{w}_{A, S}=\lambda_{A} \frac{m_{A}}{x_{O} N F} \frac{P}{v}
$$

Here $m_{O}=32 \times 10^{-3} \mathrm{~kg} /$ mole is molecular mass of oxygen, $S_{O}=1 / 2$ is oxygen stoichiometry (see cathode reaction), $m_{A}=28.97 \times 10^{-3} \mathrm{~kg} /$ mole is molecular mass of air and $x_{O}=0.2095$ is mole fraction of oxygen in dry air. For PEMFC, it is required that effective stoichiometry be at least $\lambda_{A} \approx 2.5 S_{O}$. The air supply rate minus the oxygen consumption rate is the air exhaust rate. The hydrogen consumption rate plus the oxygen consumption rate is the water exhaust rate. The later is in combined liquid and vapor form. The individual contents are calculated based on a stack pressure drop (assumed $0.3 \mathrm{~atm}$ ), the saturated vapor pressure of water at the operating temperature $80^{\circ} \mathrm{C}$, and assuming exit pressure equals vapor pressure plus dry air pressure. The humidity ratio is ratio of vapor exhaust rate to air exhaust rate. Table 2 shows the fuel flow rates for the four stacks at their rated powers. The endurance ( $5 \mathrm{~kg}$ of fuel divided by the flow rate) and capacity (rated power multiplied by endurance of the table) are also shown for reference. The required volume flow rate and high pressure operation requires a compressor. Depending on the stack operating pressure and internal pressure drop an expander can be used at the exit to recover some of this power.

\begin{tabular}{lcccc}
\hline Parameters & S2.98 & S2.68 & S3.98 & S3.68 \\
\hline \hline hydrogen in $(\mathrm{g} / \mathrm{s})$ & 1.31 & 0.90 & 1.50 & 1.04 \\
Air in $(\mathrm{kg} / \mathrm{s})$ & 0.112 & 0.0775 & 0.128 & 0.0888 \\
Air in $(\mathrm{L} / \mathrm{m})$ & 3359 & 2326 & 2568 & 1777 \\
Air out $(\mathrm{kg} / \mathrm{s})$ & 0.102 & 0.0703 & 0.117 & 0.0806 \\
Vap out $(\mathrm{kg} / \mathrm{s})$ & 0.024 & 0.017 & 0.015 & 0.0105 \\
& & & & \\
End. $(\mathrm{m})$ & 63.8 & 92.2 & 55.7 & 80.4 \\
Cap. $(\mathrm{kWh})$ & 86.5 & 86.5 & 86.5 & 86.5 \\
\hline
\end{tabular}

Table 2. Fuel flow rates for four stack designs, two each at 2 and $3 \mathrm{~atm}$, all with temperature $80^{\circ} \mathrm{C}$ and hydrogen/air stoi $1 / 2.5$; stack voltage $250 \mathrm{~V}$, humidity ratio $=0.24$; endurance shown with $5 \mathrm{~kg}$ of hydrogen; capacity is rated power $\times$ endurance (remains same for a fixed amount of hydrogen).

\section{III.A.3. Compressor-Expander (C-E)}

A compressor is needed at the inlet of the stack to compress air from ambient pressure to stack operating pressure (2 or $3 \mathrm{~atm}$ ). The compressor power is the main source of BOP loss and altitude loss. A part of this loss can be recovered using an expander (or turbine) at the outlet of the stack. The expander outlet is at ambient pressure. The compressor and expander power are calculated using isentropic assumptions. Their efficiencies are assumed to be $60 \%$.

The compressor-expander (C-E) is calibrated to an advanced unit built by Honeywell for a $80 \mathrm{kWe}$ automotive fuel cell system for DoE HP in 2005 (Fig. 8). The input power to the shaft to power the C-E or compressor only is estimated $9.4 \mathrm{~kW}$ or $15.7 \mathrm{~kW}$ for 2 or $3 \mathrm{~atm}$ operation. It assumes hydrogen and air flow of $0.09 \mathrm{~kg} / \mathrm{s}$ at full flow and outlet pressure of $2.5 \mathrm{~atm}$. It assumes expander inlet flow conditions to be 0.093 $\mathrm{kg} / \mathrm{s}, 80^{\circ} \mathrm{C}$, and $2.2 \mathrm{~atm}$. It weighs $11 \mathrm{~kg}$ and has volume $6.5 \mathrm{~L}$. Representative state of the art numbers are 
compressor efficiency of $72 \%$, capable of $2.5: 1$ pressure ratio at $0.1 \mathrm{~kg} / \mathrm{s}$ flow rate, turbine efficiency of $80 \%$, capable of $2.5: 1$ pressure ratio at $0.1 \mathrm{~kg} / \mathrm{s}$ flow rate, $6 \mathrm{~kW}$ of net power required, and sizes of around $15 \mathrm{~kg}$ and $15 \mathrm{~L} \cdot{ }^{15}$

Table 3 shows the C-E specifications and sizes for the four stacks. The weight and volume are scaled to maximum flow rates (at SL/ISA), and hence show higher values than the Honeywell unit. The maximum flow rates depend on maximum power output, hence stack pressure, so a reduction in stack pressure leads to a reduction in C-E power, as well as its size. Reduction in C-E power means an increase in net power output. From tables 3 and 2, the low power stacks (S2.68 and S3.68) appear to be near the state of the art in terms of flow rates $(0.0775,0.0888 \mathrm{~kg} / \mathrm{s})$, whereas the high power stacks (S2.98 and S3.98) are beyond state of the art.

\begin{tabular}{lcccc}
\hline Parameters & S2.98 & S2.68 & S3.98 & S3.68 \\
\hline \hline Com. T in $\left({ }^{\circ} \mathrm{C}\right)$ & 15 & 15 & 15 & 15 \\
Com. T out $\left({ }^{\circ} \mathrm{C}\right)$ & 120 & 120 & 192 & 192 \\
Com. p in $(\mathrm{atm})$ & 1 & 1 & 1 & 1 \\
Com. p out $(\mathrm{atm})$ & 2 & 2 & 3 & 3 \\
Com. P $(\mathrm{kW})$ & 11.83 & 8.19 & 22.84 & 15.81 \\
Com. P max $(\mathrm{kW})$ & 23.86 & 16.52 & 46.90 & 32.47 \\
Exp. T in $\left({ }^{\circ} \mathrm{C}\right)$ & 80 & 80 & 80 & 80 \\
Exp. T out $\left({ }^{\circ} \mathrm{C}\right)$ & 50.3 & 50.3 & 28.4 & 28.4 \\
Exp. p in $(\mathrm{atm})$ & 1.7 & 1.7 & 2.7 & 2.7 \\
Exp. p out $(\mathrm{atm})$ & 1 & 1 & 1 & 1 \\
Exp. P $(\mathrm{kW})$ & -3.77 & -2.61 & -6.95 & -4.81 \\
Exp. P max $(\mathrm{kW})$ & -7.61 & -5.27 & -14.26 & -9.87 \\
Net P $(\mathrm{kW})$ & 8.06 & 5.58 & 15.89 & 11.00 \\
Net P max $(\mathrm{kW})$ & 16.25 & 11.25 & 32.64 & 22.59 \\
& & & & \\
W $(\mathrm{kg})$ & 27.55 & 19.07 & 32.15 & 22.26 \\
V $(\mathrm{L})$ & 16.26 & 11.25 & 18.98 & 13.14 \\
\hline
\end{tabular}

Table 3. Compressor-Expander operations (SL/ISA) corresponding to four stack designs, two each at 2 and 3 atm, all with temperature $80^{\circ} \mathrm{C}$ and hydrogen/air stoi $1 / 2.5$; stack pressure loss assumed is $0.3 \mathrm{~atm}$, compressor and expander efficiencies are 0.6 .

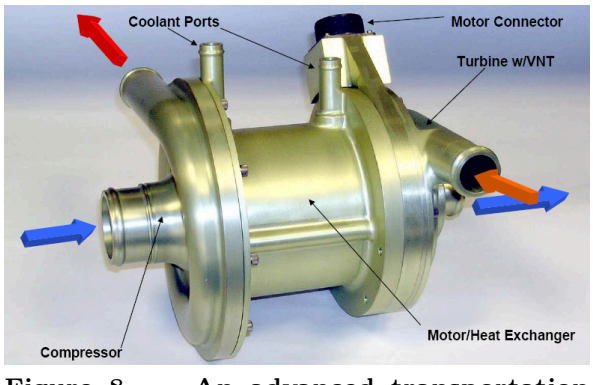

Figure 8. An advanced transportation PEM fuel cell turbo C-E from Honeywell; $6.5 \mathrm{~L}, 11 \mathrm{~kg}$; system with controller $15 \mathrm{~L}$, 17.5 kg; Gee, M. K., DOE HP Review, May $25,2005$.

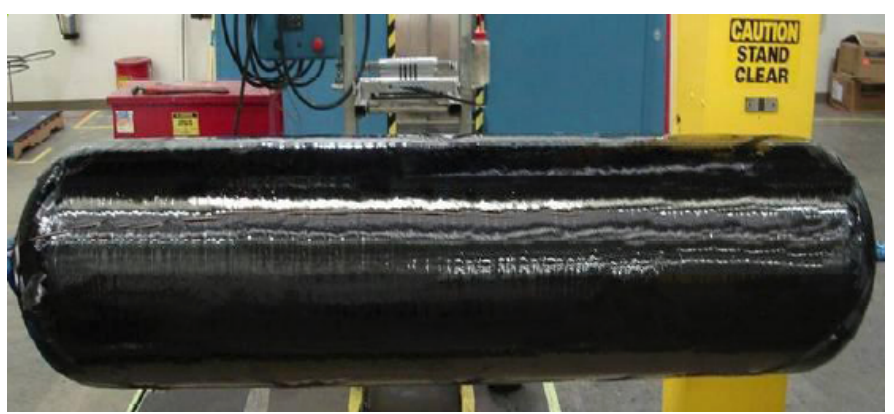

Figure 9. Compressed hydrogen (70 MPa) type 4 composite cylinder from Quantum Technologies; $5 \mathrm{~kg}$ of hydrogen; volume $129 \mathrm{~L}$, weight $92 \mathrm{~kg}$.

\section{III.B. Hydrogen storage}

\section{III.B.1. Storage tanks}

Hydrogen is the most abundant element in the universe, making up almost $75 \%$ of all matter (most of the remaining $25 \%$ is Helium), but not on earth. On earth, hydrogen must be extracted, from other sources. The density under SL/ISA is $\rho_{H, I S A}=8.525 \times 10^{-5} \mathrm{~kg} / \mathrm{L}$. The density is calculated as molar mass divided by molar volume. The molar volume is given as a function of temperature and pressure by the ideal gas law 
and the molar mass is 2.0158 grams. The density is dramatically increased under pressure. For example, $\rho_{H, 350 b}=0.0229 \mathrm{~kg} / \mathrm{L}\left(350 \mathrm{bar} / 5000 \mathrm{psi}, 21^{\circ} \mathrm{C}\right)$ and $\rho_{H, 700 b}=0.0393 \mathrm{~kg} / \mathrm{L}\left(700 \mathrm{bar} / 10000 \mathrm{psi}, 21^{\circ} \mathrm{C}\right)$. The compressibility follows ideal gas law up to around 350 bar beyond which it reduces. At 700 bar there is about $25 \%$ loss in compressibility relative ideal gas. The density of liquid hydrogen (at boiling point) is yet greater $\rho_{H, L}=0.07099 \mathrm{~kg} / \mathrm{L}$. However, significant energy is required to convert hydrogen into liquid, and the boiling point being $-252.85^{\circ} \mathrm{C}$, it must be stored well insulated at cryogenic temperatures. In comparison, the density of gasoline is $\rho_{\text {gas }}=0.72 \mathrm{~kg} / \mathrm{L}$. Thus a $\mathrm{kg}$ of hydrogen stored even in liquid form takes 10 times more space than gasoline. But a $\mathrm{kg}$ of hydrogen contains more energy. The specific energy (also called gravimetric energy density or calorific value) varies between $33-39.4 \mathrm{kWh} / \mathrm{kg}$ depending on lower or higher heating values. In comparison, the gravimetric density of gasoline is almost a third, $13 \mathrm{kWh} / \mathrm{kg}$. Thus a $\mathrm{kg}$ of hydrogen stores around 3 times more energy than a $\mathrm{kg}$ of gasoline. This is the primary motivation for using hydrogen as fuel. The energy density (also called volumetric energy density) for gasoline, which is specific energy (gravimetric energy density) times density, is $9.36 \mathrm{kWh} / \mathrm{L}$. The energy densities of hydrogen, for gas at 700 bar or liquid, are similarly calculated as $1.55 \mathrm{kWh} / \mathrm{L}$ and $2.8 \mathrm{kWh} / \mathrm{L}$ respectively. Thus, compared to gasoline, a $\mathrm{L}$ of gaseous hydrogen at 700 bar stores about 1/6-th the energy and a $\mathrm{L}$ of liquid hydrogen $1 / 3$-th the energy. These numbers, corresponding to hydrogen alone (without tank) define the theoretical upper limits for storage gravimetric and volumetric densities (with tank).

The technology levels for storage gravimetric and volumetric capacities, i.e, $\mathrm{kg}$ of hydrogen per $\mathrm{kg}$ of tank and $\mathrm{kg}$ of hydrogen per L of tank system, vary widely depending on the form of storage (compressed gas, cryogenic, cryo-compressed, solid state), measured data or analysis predictions, small-scale laboratory demonstration or production level tanks, type and material of tank construction, and the actual amount of hydrogen stored. Table 4 shows compressed hydrogen storage data from commercial on-board tank producers. Only type- 3 and -4 will be considered (type- 1 and -2 are for storage pressures lower than 350 bars; used in buses but are too heavy and large for aviation). Type-3 tanks are those which have metal liners reinforced with filament wrapping. Type- 4 tanks are more advanced, and have non-metal/plastic liners with resin impregnated filament wrappings.

\begin{tabular}{ccccccc}
\hline $\begin{array}{c}\text { Storage } \\
\text { Type }\end{array}$ & $\begin{array}{c}\text { Company/ } \\
\text { model }\end{array}$ & $\begin{array}{c}\mathrm{H} 2 \\
(\mathrm{~kg})\end{array}$ & $\begin{array}{c}\text { Tank } \\
\text { wt }(\mathrm{kg})\end{array}$ & $\begin{array}{c}\text { Tank } \\
\text { vol }(\mathrm{L})\end{array}$ & $\begin{array}{c}\text { Gravimetric } \\
(\mathrm{kg} / \mathrm{kg})\end{array}$ & $\begin{array}{c}\text { Volumetric } \\
(\mathrm{kg} / \mathrm{L})\end{array}$ \\
\hline \hline type-4, 350 b & QT/109176 & 1.32 & 16.8 & 34 & 0.0786 & 0.0388 \\
type-4, 350 b & QT/110500 & 1.55 & 20.0 & 40 & 0.0775 & 0.0388 \\
type-4, 700 b & QT/110463 & 5.00 & 92.0 & 129 & 0.0543 & 0.0388 \\
type-3, 350 b & DT/W205 & 4.89 & 95.0 & 285 & 0.0515 & 0.0172 \\
type-3, 350 b & DT/ZD154 & 3.73 & 82.0 & 231 & 0.0455 & 0.0161 \\
type-3, 350 b & DT/ZM180 & 4.26 & 93.0 & 276 & 0.0458 & 0.0154 \\
type-3, 450 b & DT/W076 & 2.17 & 53.6 & 137 & 0.0405 & 0.0158 \\
type-3, 450 b & DT/W303 & 8.64 & 170.5 & 343.5 & 0.0507 & 0.0252 \\
\hline
\end{tabular}

Table 4. Commercially available type 3 and 4 composite tanks; QT: Quantum Technologies, DT: Dynetek Industries Ltd.

In terms of usage in automobiles, the Honda FCX 2005 stored $3.75 \mathrm{~kg}$ of hydrogen in $156.6 \mathrm{~L}$ of tanks - two tanks of $66 \mathrm{~L}$ and $88 \mathrm{~L}$ each - at 350 bar. But the weights of the tanks are not disclosed. Thus volumetric density is $0.0239 \mathrm{~kg} / \mathrm{L}$ but gravimetric capacity is unknown. The Honda Clarity 2009 stores $3.92 \mathrm{~kg}$ of hydrogen in a single $171 \mathrm{~L}$ tank at 350 bar. Even though the space efficiency is declared to have increased by $24 \%$ going from two to one tank, for design purposes we will consider volumetric density purely on the basis of tank volume. Thus volumetric density is $0.0229 \mathrm{~kg} / \mathrm{L}$. But the tank weight is again undisclosed so that the gravimetric capacity is unknown. The BMW hydrogen 7, introduced in 2006, stores $8 \mathrm{~kg}$ of liquid hydrogen in $170 \mathrm{~L}$ of space (the liquid hydrogen by itself is about $114 \mathrm{~L}$ in volume). This car uses hydrogen as fuel for a combustion engine not a fuel cell. The tank weight is undisclosed. Given that the car weighs around $220 \mathrm{~kg}$ more than its non-hydrogen counterpart and assuming $90 \%$ of this increase is for hydrogen storage the gravimetric capacity can be estimated conservatively as $0.04 \mathrm{~kg} / \mathrm{kg}$. The volumetric capacity is $0.047 \mathrm{~kg} / \mathrm{L}$ of storage. In a press release in 2008 , BMW stated a potential $10 \mathrm{~kg}$ storage with $1 / 3$ the weight of its current steel tank. Precise data is unavailable. With a conservative assumption in reduction, say by only $30 \%$ in weight and $20 \%$ in volume, the new tank system would be $140 \mathrm{~kg}$ and $136 \mathrm{~L}$, and produce capacities of $0.057 \mathrm{~kg} / \mathrm{kg}$ and $0.059 \mathrm{~kg} / \mathrm{L}$ for $8 \mathrm{~kg}$ of liquid hydrogen. 


\begin{tabular}{lcc}
\hline $\begin{array}{l}\text { Storage } \\
\text { type }\end{array}$ & $\begin{array}{c}\text { gravimetric } \\
(\mathrm{kg} / \mathrm{kg} \text { system })\end{array}$ & $\begin{array}{c}\text { volumetric } \\
(\mathrm{kg} / \mathrm{L} \text { system })\end{array}$ \\
\hline \hline III, 350 bar & 0.042 & 0.0174 \\
IV, 350 bar & 0.055 & 0.0176 \\
III, 700 bar & 0.036 & 0.0250 \\
IV, 700 bar & 0.052 & 0.0263 \\
Liq. H & 0.057 & 0.023 \\
Cc H $\mathrm{H}_{2}$ (steel shell) & 0.055 & 0.0411 \\
$\mathrm{Cc} \mathrm{H}_{2}$ (Al shell) & 0.090 & 0.0411 \\
2010 target & 0.045 & 0.028 \\
2015 target & 0.055 & 0.040 \\
Ultimate & 0.075 & 0.070 \\
\hline
\end{tabular}

Table 5. Technology levels for hydrogen storage from DoE Hydrogen Program; based on $5.6 \mathrm{~kg}$ of stored hydrogen.

Table 5 shows analytical estimates for a variety of on-board storage systems from the DoE HP for $5.6 \mathrm{~kg}$ of hydrogen. Even though the DoE targets are meant to reflect requirements, not status of technology, these estimates are representative of what is achievable. The table shows current technology meets earlier 2010 targets but falls short of 2015 targets in volumetric capacity. The ultimate targets for volumetric capacity are yet higher. The ultimate targets for gravimetric capacities are met today but only for small quantities of hydrogen. Storage based on metal hydride and other solid state technologies are not considered. These technologies promise high volumetric capacity but presently have poor gravimetric capacities (around 0.0065 $\mathrm{kg} / \mathrm{kg}$ of storage).

Hydrogen storage is a topic of continuing basic research. The present design is therefore calibrated to measured data. Specifications based on the type-4, 700 bar, QT/110463 tank (Fig. 9) are considered as baseline, even though the hydrogen storage amounts considered will vary between $1.63-7.20 \mathrm{~kg}$.

\section{III.B.2. Stack-storage combined system}

The stack and storage are not designed in isolation, but considered together. The stack-storage combination also determines the trade-off between power and energy. Ragone plots show the power and energies possible from a stack-storage system of fixed total weight, as the individual stack and storage weight fractions are varied. Note that the plots do not depend on the actual weight, but only on the technology level $(i-v$ characteristics, stack construction, and storage type) and operating conditions (cell voltage, anode/cathode humidity and stack pressure). The final stack designs shown earlier were chosen based on this combined analysis.

The variation of specific power with specific energy and with energy density for various design cell voltages are shown in Figs. 10 and 11 respectively. To generate the plots, fuel system weight fraction is varied from $10 \%$ to $90 \%$ (with corresponding stack weight fraction varied from $90 \%$ to $10 \%$ ). A 700 bar, type- 4 hydrogen storage is considered. The plots show the trade-off between rate of discharge and time of discharge for a fixed total energy (here, for $5 \mathrm{~kg}$ hydrogen). The left side of the plot indicates higher rate of discharge (greater power), the right side of the plot indicates lower rate of discharge (lower power). The plot also shows the limits of specific power and specific energy of the fuel cell system. The trade-off and the limits depend strongly on the design cell voltage. Clearly, there is no reason to operate below $0.55 \mathrm{~V}$. But at or above 0.55 $\mathrm{V}$, the most suitable voltage depends on the intended time of operation and targets. For $15-30$ min worth of operation clearly $0.55 \mathrm{~V}$ is most suitable. For $30-60 \mathrm{~min} 0.55 \mathrm{~V}$ is most suitable only if maximizing specific energy is the target. If energy density is of greater concern, $0.60 \mathrm{~V}$ is more suitable. Greater energy targets (whether specific or density) reduce specific power accordingly, but energy levels available from fuel cells being far superior to other electrochemical devices, maximizing energy is almost always the target as long as minimum power requirements are met. It is shown later, weight is of greater concern than volume (for the present power target), thus from Fig. 10, $0.60-0.65 \mathrm{~V}$ appear the most suitable for a wide range $(1-4 \mathrm{hr})$ of operating time.

The effect of hydrogen storage technology is shown in Figures 12 and 13 for $0.60 \mathrm{~V}$ design cell voltage (the plot for $0.65 \mathrm{~V}$ is similar). From Fig. 12, it appears all current storage types coalesce to a similar plot level whereas DoE 2015 target calls for a dramatic improvement. This improvement is essential for 


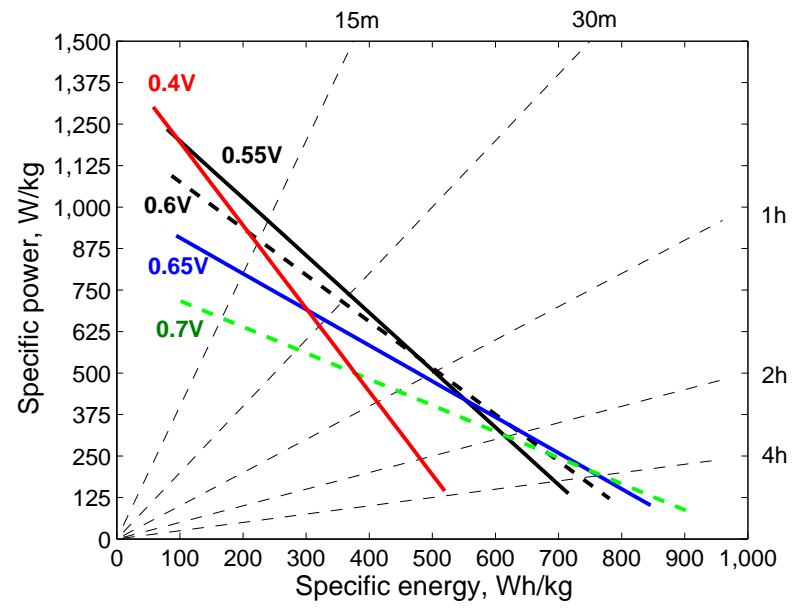

Figure 10. Ragone plot (linear scale), sp. power vs. sp. energy for any total weight of stack plus fuel storage combined, for various cell voltages; variation of stack and fuel storage is from $10 \%$ stack-90\% storage to $90 \%$ stack-10\% storage; storage is 700 bar type-4 tanks.

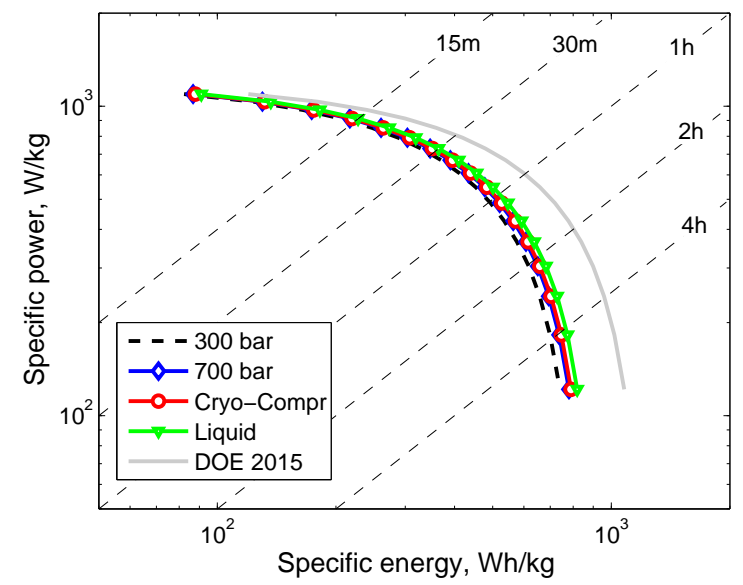

Figure 12. Effect of hydrogen storage technology on Ragone plot (log scale) of specific power vs. specific energy; cell voltage $0.6 \mathrm{~V}$.

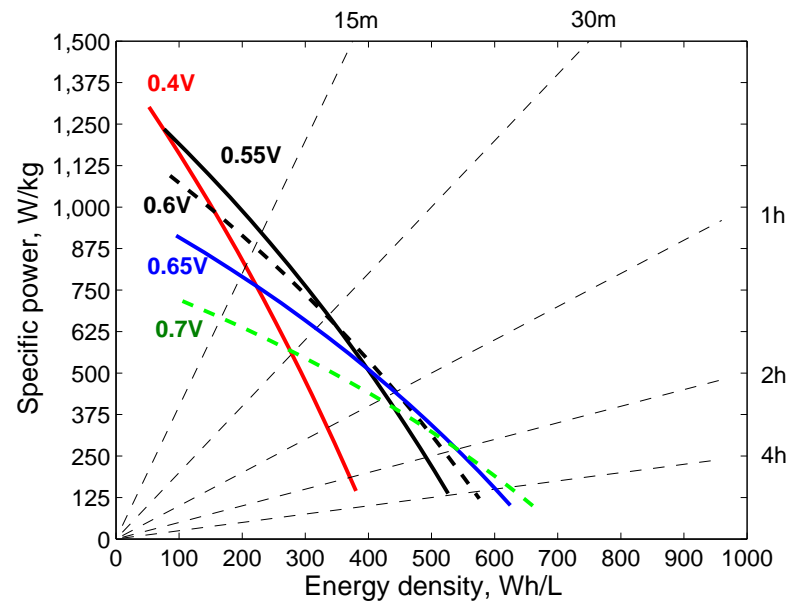

Figure 11. Ragone plot (linear scale), sp. power vs. energy density for any total weight of stack plus fuel storage combined, for various cell voltages; variation of stack and fuel storage is from $10 \%$ stack-90\% storage to $90 \%$ stack-10\% storage; storage is 700 bar type4 tanks.

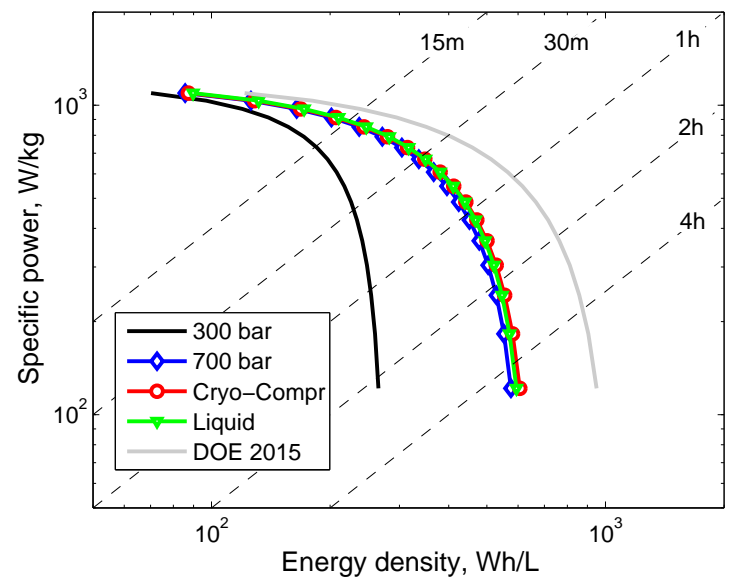

Figure 13. Effect of hydrogen storage technology on Ragone plot (log scale) of specific power vs. energy density; cell voltage $0.6 \mathrm{~V}$.

aviation purposes. From Fig. 13, it is obvious that 700 bar storage is superior to 350 bar, but beyond that all storage technologies coalesce again. Both figures appear to indicate that there is no significant advantage in using liquid hydrogen over 700 bar gaseous hydrogen, with current technology . Thus, the additional cost of liquefaction and weight of cryogenic storage is best avoided at the power levels of present interest.

\section{III.C. Lithium ion battery pack}

Among the various Lithium-ion chemistries, Lithium-ferro-phosphate $\left(\mathrm{LiFePO}_{4}\right)$ is often considered to be superior in safety (under wide temperature variations and over/under charging). However, no preference is given to cell chemistries here, data from more common consumer grade lithium cobalt oxide $\left(\mathrm{LiCoO}_{2}\right)$ and lithium manganese oxide $\left(\mathrm{LiMn}_{2} \mathrm{O}_{4}\right)$ chemistries are also considered.

Typical discharge curves under constant current for lithium-ion cells are shown in Fig. 14. These curves correspond to Nissan Leaf-like cells rated at (0.3C)33 Ah (the notation means 33 Ah delivered when current drawn is $0.3 \mathrm{C}=0.3 \times 33=9.9 \mathrm{~A}$, where $\mathrm{C}$ denotes current of same amount in $\mathrm{A}$ as capacity in Ah; also means a corresponding discharge time of $1 / 0.3=3.33 \mathrm{hrs}$ ).

The discharge curve at $0.3 \mathrm{C}$ is considered the baseline. The discharge curves at other currents are then found using an elementary battery model consisting of an incremental internal resistance and a Peukart 


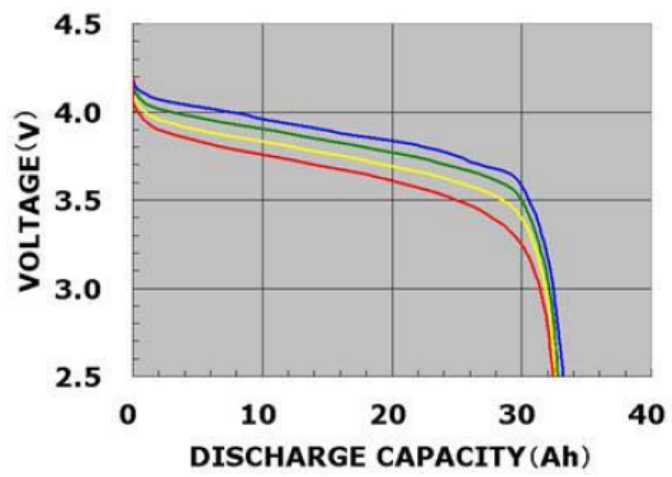

Figure 14. Discharge profiles of Nissan Leaf-like cells; rated as (0.3C) $33 \mathrm{Ah}$; public data from American Energy Supply Corporation (AESC).

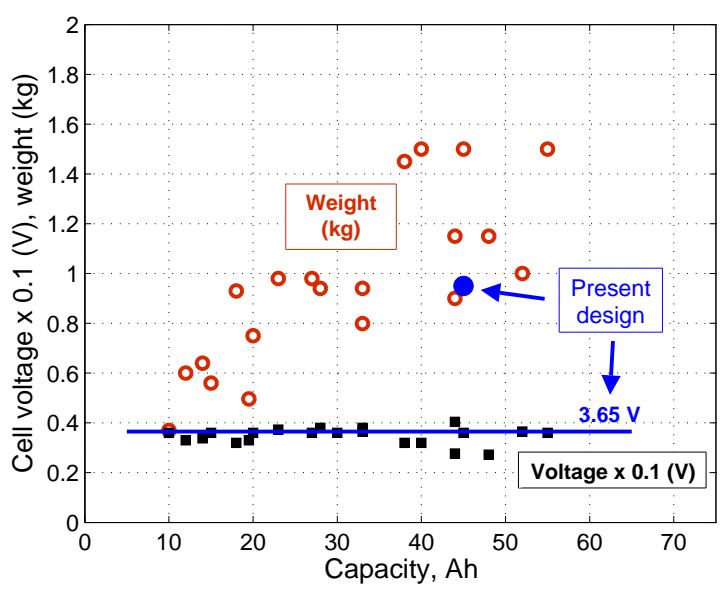

Figure 16. State of the art in Li-ion cells, cell voltage and weight vs. capacity; data compiled from six manufacturers (AESC, SAFT, LTC, A123, Ping, and Winstone).

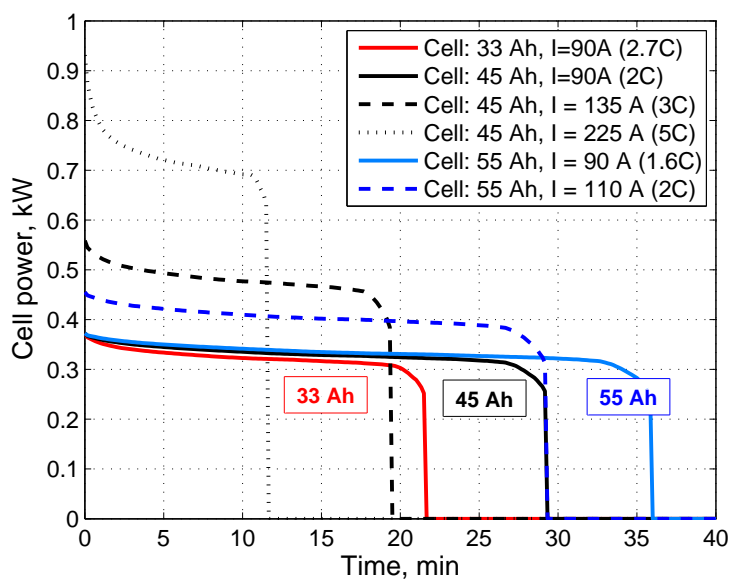

Figure 18. Various power profiles calculated using current technology high-power Li-ion cells; only continuous power considered not 2s-20s short impulses.

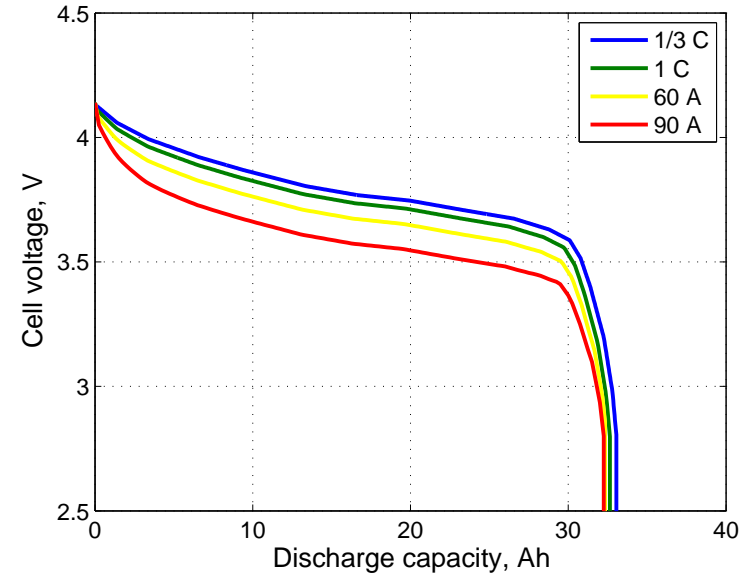

Figure 15. Simulated discharge profiles of $(0.3 C) 33$ Ah cells using an elementary battery model; resistance and Peukart coefficient chosen to match NISSAN LEAF like behavior.

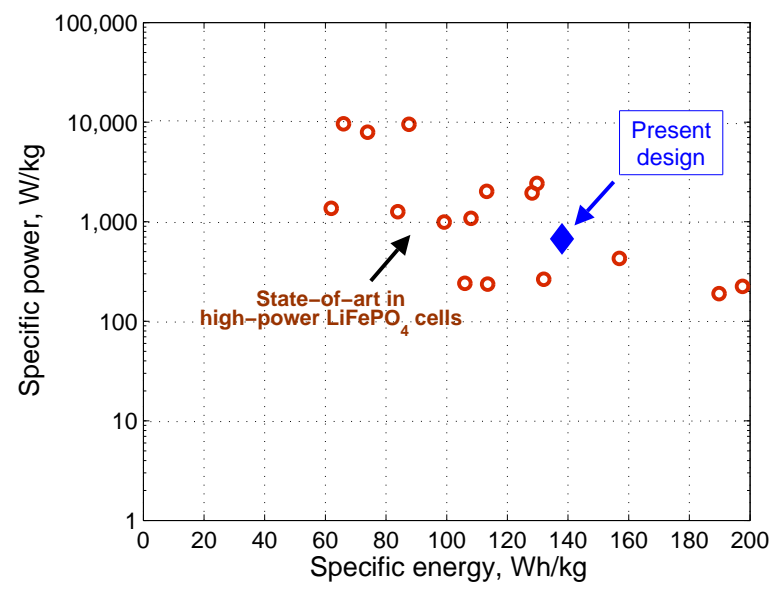

Figure 17. State of the art in Li-ion cells, cell sp. power vs. sp. energy; data compiled from six manufacturers (AESC, SAFT, LTC, A123, Ping, and Winstone).

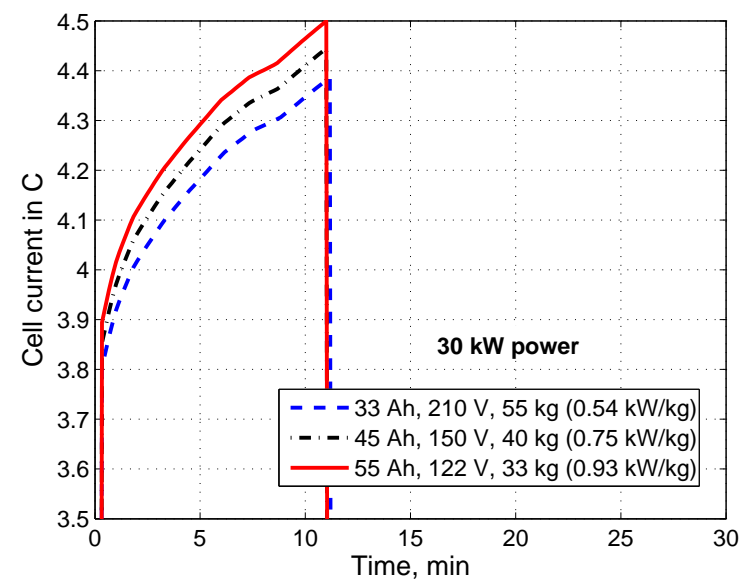

Figure 19. Cell current (in fraction of capacity value) to deliver $30 \mathrm{~kW}$ power for $12 \mathrm{~min}$ using three types of cells 33 Ah (NISSAN LEAF-like tech. level), 45 Ah (Sikorsky Firefly-like tech. level), and 55 Ah ( hypothetical desired tech level). 
coefficient. These values are set to reproduce published data at the other current levels. A refined battery model will contain two Resistor-Capacitor circuits in series with another Resistor to reproduce the transient voltage current characteristics (in place of the incremental internal resistance) and another R-C circuit to reproduce the variation of capacity with discharge rate (in place of the Peukart coefficient), ${ }^{18}$ but identifying these parameters from data that is available in public domain is beyond scope of this paper. Hence direct use of data is made as much as possible. The Peukart coefficient and the internal resistance are set to $k=1.01$ and $r=r_{0}(1+I f)$, where $r_{0}$ is a constant resistance, $I$ is the current in $C$ (in fraction of the rated capacity, $33)$, and $f$ is a factor that depends on the depth of discharge $x, f=1-\exp [-20 x]-\exp [-20(1-x)]$. Figures 14 and 15 show data and analysis results respectively.

The area under each curve gives the energy content for the given discharge current. Energy content divided by the maximum discharge capacity gives the nominal voltage. Energy content divided by the weight of each cell gives specific energy. For the Leaf, energy content is 125 Wh (total energy $24 \mathrm{kWh}$ supplied by 192 cells) and each cell weighs $0.8 \mathrm{~kg}$. The total battery weight is $272 \mathrm{~kg}$ however, which means there is an overhead of around $0.6 \mathrm{~kg} /$ cell. If only the cell weight is considered, the specific energy is $125 / 0.8=150 \mathrm{kWh} / \mathrm{kg}$. If the overhead is included, it is $125 / 1.4=90 \mathrm{kWh} / \mathrm{kg}$. These are poor numbers for purposes of aviation. The power delivered is the current times the voltage shown in the above profiles. Power divided by the weight of each cell gives specific power. Greater power means greater current and the limit to maximum power is set by maximum continuous current that can be drawn without damaging the cell. Maximum continuous current is an important cell specification and for it to be high is a key requirement for aviation.

The state of the art in commercially available/custom made lithium-ion cells suitable for aviation ranges from $20 \mathrm{Ah}-55 \mathrm{Ah}$ capacities. Below $20 \mathrm{Ah}$, energy content is too low. Above $55 \mathrm{Ah}$, maximum current is limited. Consider some of the commercial off the shelf (COTS) lithium-ion cells available today. The cell weights approximately track capacity as shown in Fig. 16. The data points include AESC (supplier of Nissan Leaf), LTC (supplier of Sikorsky Firefly), SAFT, A123, Winston, and Ping. Cells targeted for high power lie at the lower end (20-45Ah) but can sustain 3C-5C of continuous current. Cells targeted for high energy lie at the higher end (45-55Ah) but are limited to $1 \mathrm{C}-2 \mathrm{C}$ (similar current levels in A). Thus for purposes of design, a high capacity cell cannot simply be picked and driven to higher power, the current must be restricted within limits. Within this limitation, the specific power vs. specific energy of the above cells are shown in Fig. 17. The maximum current rating of the Leaf cells is unknown, so 90A has been assumed (since published discharge profile in Fig. 14 includes up to this value). Note that the maximum current rating is often quoted for $2 \mathrm{~s}$ or $20 \mathrm{~s}$ impulses. These are only relevant for short time dashes, but are irrelevant for sustained high power requirements. Specific power numbers quoted using these special cases cannot be used as basis for selection. Specific energy is the proper basis, because even though the current drawn will differ from the value at which the capacity is rated, the Peukart coefficients of all lithium-ion cells are close to 1.

Figure 18 shows the power profiles of several current technology cells calculated by applying the battery model. From the Leaf cells operating at 90A, the capacity is increased to include two other cells. The 45 $\mathrm{Ah}$ cells have maximum continuous current rating of around 5C (although the recommended operation is still within $2 \mathrm{C}$ ). The $55 \mathrm{Ah}$ cells have maximum continuous current rating of only $2 \mathrm{C}$. Figure 18 shows the maximum power that can be delivered by these high energy cells. For example, it is clear that for 20 min of power assist $45 \mathrm{Ah}$ cells will be the most appropriate. The $33 \mathrm{Ah}$ cells would not last as long and the $55 \mathrm{Ah}$ cells will not deliver as much power. Thus, not only improved capacity is required but constructions that allow higher continuous current ratings.

For illustration, consider three cells rated $33 \mathrm{Ah}, 45 \mathrm{Ah}$, and $55 \mathrm{Ah}$. If a battery were to be constructed that could deliver $30 \mathrm{~kW}$ over 12 min (at which point they will all be $80 \%$ discharged) then their minimum weights are found to be 55, 40, and $33 \mathrm{~kg}$ with operation at 210,150, and $122 \mathrm{~V}$. The current drawn would vary from $3.5 \mathrm{C}-4.5 \mathrm{C}$ and follow the profiles shown in Fig. 19. These currents are at the high-end of what are potentially feasible today. But if possible, they will provide potential advantages when used in a battery fuel cell-hybrid power plant to assist in the hover and climb operations. The specific power of even the first cell $(33 \mathrm{Ah})$ is comparable to that of the fuel cell, hence a part of the power plant can be replaced with a battery made up of such cells without changing the total power plant weight, and, the fuel cell, now having to supply less power will extend range with the same fuel (or carry more payload over same range). However, if maximum current is limited, then more cells must be added (to increase voltage and decrease current), which implies carrying excess capacity and excess weight. 


\section{III.D. Electric motor}

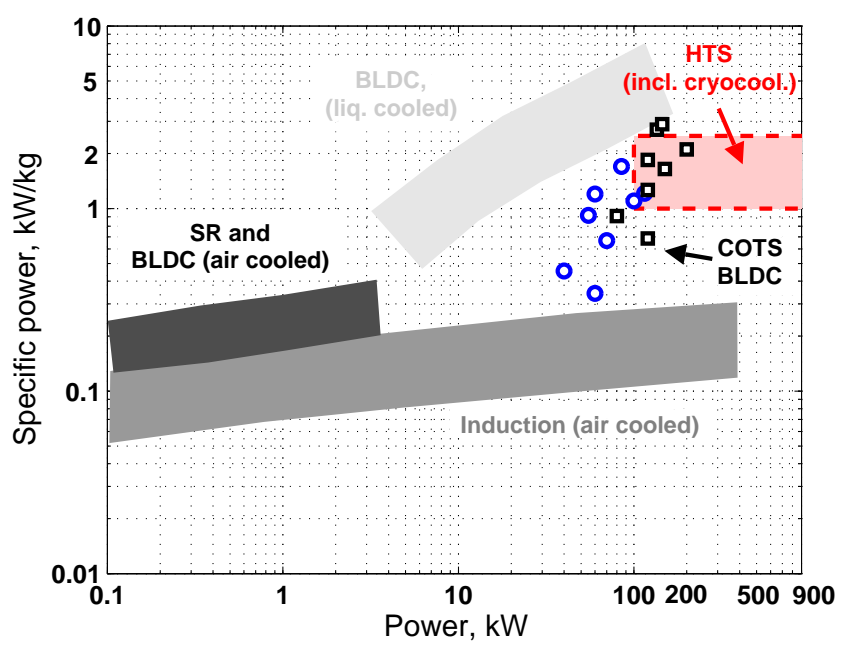

Figure 20. State of the art in electric motors applicable to HEVs and EVs; symbol- $\square$ is data calculated using maximum power, symbol- $\circ$ is data calculated using continuous power.

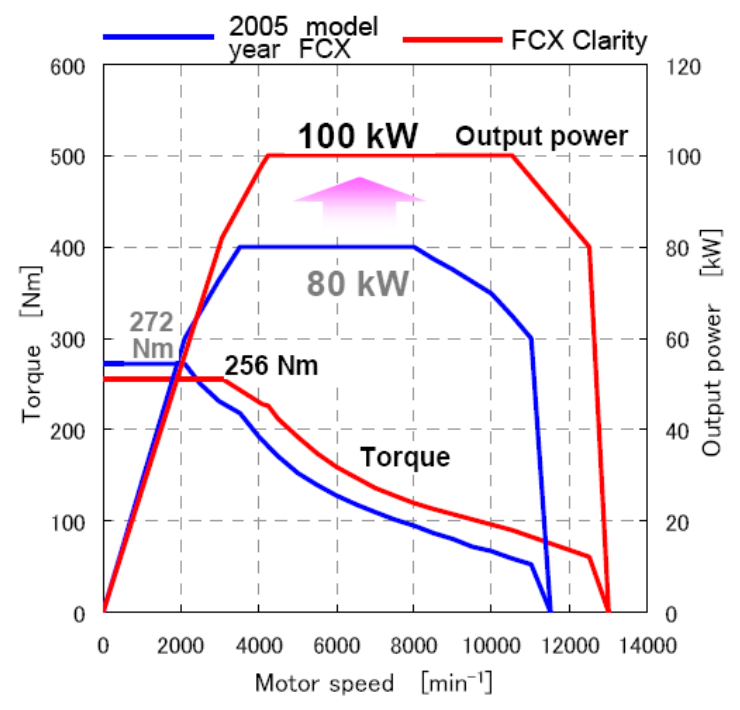

Figure 21. Power and torque vs. speed characteristics of Honda FCX Clarity (2009) and FCX $\underset{\text { tors }}{2005}$ AC synchronous permanent magnet mo-

The electric motors used in HEVs and EVs are mainly of two types: AC synchronous permanent magnet motors (EVs: Honda FCX and Clarity fuel cell cars, Nissan Leaf, Chevy Equinox fuel cell car, Chevy Sequel fuel cell car, etc; HEVs: Chevy Volt, Nissan Tino, Honda Insight, Toyota Prius, etc) and AC induction motors (EVs: Tesla, BMW Mini E, etc). Some simple/early applications use DC motors (also popular for home-built EV conversions ${ }^{17}$ ) and some new applications explore switched reluctance motors but their specific powers are too poor for any consideration at this stage. AC synchronous permanent magnet motors are also referred to as Brushless DC motors. Brushless DC motors are not DC motors, they are identical to AC synchronous permanent magnet motors in configuration and mechanism. But when termed Brushless DC, it implies the motor system includes a controller/inverter to convert DC to AC, so can be used as a replacement for a brushed DC motor. If termed $\mathrm{AC}$ synchronous, it means the motor can be operated directly from an AC source. Thus, keeping aside the controller, AC synchronous permanent magnet motors are same as brushless DC motors. Note that the permanent magnet here refers to the rotor, not the stator, as in permanent magnet DC motors. Earlier, in brushless DC motors, the stator was trapezoidally wound to produce trapezoidal flux density in the air gap of the machine (and hence a trapezoidal back e.m.f.) whereas in a permanent magnet synchronous motor the stator winding is constructed so as to produce a sinusoidal flux density in the air gap of the machine. The latter is similar to that of AC induction motors. Hence permanent magnet synchronous motors could be thought of as in-between brushless DC and AC induction motors. Today, most brushless DC motors are sinusoidally wound anyway, so this distinction has vanished. In this paper we use the term brushless DC (BLDC) only.

BLDC motors that are liquid cooled have the highest specific power of all motors in the power range of interest. The state of the art in electric motors is summarized in Fig. 20. The baseline trends are taken from Ref. 16, the data points are obtained from several motor manufacturers, among which are US Hybrid (Sikorsky Firefly supplier) and UQM (Boeing fuel cell airplane supplier). The specifications of a few of these COTS motors (that are available in public domain) in a similar power range as required here are shown in Table 6. Motor-6 appears marginally appropriate for the $\mathrm{R} 22$ as it is capable of $85 \mathrm{~kW}$ of continuous power compared to $93 \mathrm{~kW}$ of the original power plant. A more suitable motor is Motor-7. This is capable of 100 $\mathrm{kW}$ of continuous power but is twice as heavy - $91 \mathrm{~kg}$ compared to $50 \mathrm{~kg}$. It is assumed that a motor can be custom made to maintain similar size characteristics of Motor- $6-1.7 \mathrm{~kW} / \mathrm{kg}$ and $4.78 \mathrm{~kW} / \mathrm{L}$ - so that for $93 \mathrm{~kW}$ of continuous power (and $97.5 \mathrm{~kW}$ of maximum) estimated size is $54.7 \mathrm{~kg}$ and $19.5 \mathrm{~L}$. It is expected to have slightly higher Q $\max (\mathrm{Nm})$ and lower Speed (RPM).

While synchronous permanent magnet motors are well suited for the power range of interest here, induction motors are the industry work-horse for high power applications. Some EV manufacturers prefer induction motors because permanent magnets imply a reliance on rare earth metals. However, they are very 


\begin{tabular}{ccccccc}
\hline $\begin{array}{c}\text { Motor } \\
\text { no. }\end{array}$ & $\begin{array}{c}\text { P max/cont } \\
(\mathrm{kW})\end{array}$ & $\begin{array}{c}\text { Q max } \\
(\mathrm{Nm})\end{array}$ & $\begin{array}{c}\text { Speed } \\
\mathrm{RPM}\end{array}$ & $\begin{array}{c}\text { voltage } \\
\mathrm{V}\end{array}$ & $\begin{array}{c}\text { weight } \\
(\mathrm{kg})\end{array}$ & $\begin{array}{c}\text { volume } \\
(\mathrm{L})\end{array}$ \\
\hline \hline 1 & $120 /-$ & 1200 & $2500(\max )$ & $250-700 \mathrm{DC}$ & 95 & 64 \\
2 & $120 /-$ & 450 & $4500(\max )$ & $250-700 \mathrm{DC}$ & 65 & 29 \\
3 & $80 / 40$ & 250 & $5000(\max )$ & $288 \mathrm{DC}$ & 88 & 18.5 \\
4 & $120 / 60$ & 635 & $5000(\max )$ & $288 \mathrm{DC}$ & 175 & 39.8 \\
5 & $135 / 60$ & 340 & $2500(@ \mathrm{Q} \max )$ & $270-425 \mathrm{DC}$ & 50 & 17.8 \\
6 & $145 / 85$ & 400 & $2000(@ \mathrm{Q} \max )$ & $340-420 \mathrm{DC}$ & 50 & 17.2 \\
7 & $150 / 100$ & 650 & $1000(@ \mathrm{Q} \max )$ & $340-420 \mathrm{DC}$ & 91 & 31 \\
8 & $200 / 115$ & 900 & $1200($ @ Q max $)$ & $340-420 \mathrm{DC}$ & 95 & 32 \\
\hline
\end{tabular}

Table 6. Commercially available motors having power ratings similar to that required for a hydrogen helicopter; 5-8 are motor-generators.

heavy for aviation. Over the last two decades, there has been significant research and development efforts in the area of High Temperature Superconducting (HTS) machines (motors and generators). ${ }^{19}$ This effort has focused largely on submarine applications where, like rotorcraft, high specific torque is as important a requirement as high specific power. Today, HTS motors are being introduced for submarine applications of up to $35 \mathrm{MW}$ of power. For aviation, paper studies have been conducted, beginning from as early as two years after its discovery in 1985 (see Ref. 20 for a study including a heavy-utility CH-53 helicopter) to a recent NASA/DoD university program (see Ref. 21 for studies ranging from Cessna 172 to heavy utility airplanes). The state of the art today is that below a power level of $746 \mathrm{~kW}(1000 \mathrm{hp})$, requirements of cryocooling more than offset the significant gains in specific power obtained from the motor alone. Including cryocooling, HTS induction motors today can provide more than twice the specific power relative conventional induction motors (with potential for even greater improvements) but still fall short of BLDC motors at the low power range. Specialized designs may be possible in this range but cannot be used as a reliable basis for present design. An approximate band for such motors in the power range of interest is shown in Fig. 20.

Transmission requirements are unique in rotorcraft. The high torque-low RPM requirements for the helicopter rotor are typically an order of magnitude different from what is considered high torque-low RPM in electric motors for automobiles. For example, the present helicopter rotor operates at around $2000 \mathrm{Nm}-510$ RPM (RPM is nominally constant in helicopter rotors within $\pm 5 \%$ variation) whereas the closest operation of the Honda BLDC motor is around $200 \mathrm{Nm}-4000 \mathrm{RPM}$ at the rated power (Fig. 21). The engine speed of the R 22 being 2652 RPM, use of this motor can only increase transmission weight. This is why Motor- 6 with maximum power speed of around 2000 RPM is chosen as the baseline for the present study. The transmission can then be assumed to remain the same. Typically, the ability to produce higher torque leads to a heavier motor. Higher torque also leads to lower efficiencies. Motor efficiency can be approximated by $\eta_{M}=P /\left(P+k_{c} Q^{2}+k_{i} \omega+k_{w} \omega^{3}+C\right)$ where $P$ is power, $Q$ is torque, $k_{c}, k_{i}, k_{w}$ are the copper, iron, and windage loss factors and $C$ is a constant. The copper loss, a key loss in motors, depends on torque not power. But higher torque means lower RPM hence a lighter transmission (assuming stress levels from higher torque remain within limits). Thus, design of the motor and transmission must be considered together for a new aircraft. 


\section{Characteristics of the All-electric Power Plant}

The power plant is sized to provide a maximum net power of $97.5 \mathrm{kWe}$ at SL/ISA - the original engine maximum derated power. Two options are considered in detail, a fuel cell-only (FC-only) option, and a battery fuel cell-hybrid (BFC-hybrid) option. A third option, the battery-only (B-only) option, is considered only for comparison purposes due to its limited range. By options, primary power sources are meant, auxiliary power (for start-up, on-board electrical systems, etc) will always require some back-up batteries.

\section{IV.A. Power plant size}

\section{IV.A.1. Fuel cell-only (FC-only) power plant}

The fuel cell-only (FC-only) power plant consists of the S2.98 stack and corresponding C-E, hydrogen storage at 700 bar in a type- 4 tank, and a BLDC motor. The weights of the components are shown in Tab. 7. The stack size is guided by Honda Clarity 2009, the C-E size by Honeywell's DoE 2005 unit, hydrogen storage by QT/110463 tank, and the Motor-6 (see previous section). The motor and controller needed by the C-E uses Honeywell numbers ${ }^{15}$ directly. The water management, thermal management, power electronics, and other accessory weights are assumptions. The entire fuel cell system has specific power $=97.5 \mathrm{~kW} / 150.2 \mathrm{~kg}$ $=0.65 \mathrm{~kW} / \mathrm{kg}$, and power density $=97.5 \mathrm{~kW} / 143.26 \mathrm{~L}=0.68 \mathrm{~kW} / \mathrm{L}$. The DoE 2015 targets for affordable automobile fuel cell systems are $0.65 \mathrm{~kW} / \mathrm{kg}$ and $0.65 \mathrm{~kW} / \mathrm{L}$, hence the current design is at the high-end for automobile systems. Including the fuel system, the specific power reduces to $0.47 \mathrm{~kW} / \mathrm{kg}$ and $0.41 \mathrm{~kW} / \mathrm{kg}$, for 2.61 and $4.12 \mathrm{~kg}$ hydrogen respectively.

For the original aircraft, the power plant weight was $117 \mathrm{~kg}$ (manufacturer's engine dry weight only). That power plant is now replaced with a new system of $209.9 \mathrm{~kg}$. This is an increase of $92.9 \mathrm{~kg}$ and is also greater than the original power plant and fuel system weights combined, by $7.9 \mathrm{~kg}$. Thus, the new payload (PL) must be lower than the original PL. The original PL cannot be flown at all. The original power plant volume was $362 \mathrm{~L}$ (from manufacturer's engine dimensions only). This is replaced with a new system of much lower volume, 167.76 L. Thus, ignoring details of packaging, volume itself is not a concern.

For the original aircraft, the fuel system weight was $85 \mathrm{~kg}$. This is now replaced with a new hydrogen storage system. A storage of $5 \mathrm{~kg}$ hydrogen increases it to $102 \mathrm{~kg}(5 \mathrm{~kg}$ hydrogen $+92 \mathrm{~kg}$ tank at 0.0543 $\mathrm{wt} \%+5 \mathrm{~kg}$ of accessories). A storage of $4.12 \mathrm{~kg}$ hydrogen keeps the fuel system weight the same. The original fuel system volume was $112.25 \mathrm{~L}$. A storage of $4.12 \mathrm{~kg}$ will need a similar volume, $108.19 \mathrm{~L}$.

For the original aircraft, maximum GTOW was $622 \mathrm{~kg}$ and empty weight was $388 \mathrm{~kg}$, so useful weight was $234 \mathrm{~kg}$. Assuming maximum fuel is flown, the PL must equal $622-388-81=153 \mathrm{~kg}$. This is the original PL with which the new aircraft is compared. For the new helicopter, if the fuel system weight is to be kept same as the original aircraft ( $85 \mathrm{~kg}$ ), the increase of $92.9 \mathrm{~kg}$ in power plant weight will mean reducing the PL to $153-92.9=60.1 \mathrm{~kg}$. This is the new PL that can be carried with the same fuel system weight. This cannot be a manned option, so the fuel system weight must be reduced. A PL of $90 \mathrm{~kg}$ ( $59 \%$ of original $153 \mathrm{~kg}$, equivalent to one person + baggage) will reduce the fuel system weight from $85 \mathrm{~kg}$ to $85-(90-60.1)=55.1 \mathrm{~kg}$, and will allow a modest fuel of $2.61 \mathrm{~kg}$. A slightly greater PL of $109 \mathrm{~kg}(71 \%$ of original $153 \mathrm{~kg}$, maximum per seat weight including baggage compartment), will require reducing the fuel system weight further down to $36.1 \mathrm{~kg}$, which will allow only a meager $1.63 \mathrm{~kg}$ of hydrogen. The fuel cell-only power plant in Table 7 shows the two fuel systems corresponding to $4.12 \mathrm{~kg}$ and $2.61 \mathrm{~kg}$ of hydrogen corresponding to PL of $60 \mathrm{~kg}$ (unmanned) and $90 \mathrm{~kg}$ (manned). A summary is given below for GTOW of $622 \mathrm{~kg}$.

Weight of empty aircraft - old power plant - old tank $=388-117-4=267 \mathrm{~kg}$.

Weight of empty aircraft + new power plant + new tank for $2.61 \mathrm{~kg}$ hydrogen $=532.58 \mathrm{~kg}$. $\mathrm{PL}=\mathrm{GTOW}-532.58=89.42 \mathrm{~kg}$ (manned, but solo pilot).

Weight of empty aircraft + new power plant + new tank for $4.12 \mathrm{~kg}$ hydrogen $=561.90 \mathrm{~kg}$. $\mathrm{PL}=\mathrm{GTOW}-561.90=60.10 \mathrm{~kg}$ (unmanned)

Note that the weight problem above is because the fuel cell stack is being designed to provide maximum power all by itself (w/o battery assist) whereas its main strength lies in high specific energy. Maximum power determines weight, hence weight is too high, and this reduces the weight of fuel that can be carried. Therefore the chief advantage of using a fuel cell - extracting energy efficiently from a high energy fuel is not being adequately drawn upon. 


\begin{tabular}{|c|c|c|c|c|}
\hline Power Plant & & Weight (kg) & Volume (L) & \\
\hline \multicolumn{5}{|l|}{ Fuel cell } \\
\hline Stack & & 89.15 & 73.50 & \\
\hline Accessories & & 5.00 & 5.00 & \\
\hline \multicolumn{5}{|l|}{ Air management } \\
\hline Compressor & & 27.55 & 16.26 & \\
\hline Motor/Controller & & 6.50 & 8.50 & \\
\hline \multicolumn{5}{|l|}{ Water management } \\
\hline Humidifier & & 5.00 & 15.00 & \\
\hline Condenser/tank & & 2.00 & 5.00 & \\
\hline \multicolumn{5}{|l|}{ Thermal management } \\
\hline Exchangers & & 4.50 & 3.00 & \\
\hline Radiator & & 7.50 & 15.00 & \\
\hline Air cooler & & 3.00 & 2.00 & \\
\hline \multicolumn{5}{|l|}{ Power electronics } \\
\hline Control system & & 2.00 & 2.00 & \\
\hline Back-up batteries & & 3.00 & 3.00 & \\
\hline \multicolumn{5}{|l|}{ Drive system } \\
\hline Motor & & 54.70 & 19.50 & \\
\hline Transmission & & -same- & -same- & \\
\hline Sub-total & & 209.90 & 167.76 & \\
\hline Fuel system & Weight (kg) & Volume (L) & Weight (kg) & Volume $(\mathrm{L})$ \\
\hline Hydrogen & 2.61 & -in tank- & 4.12 & -in tank- \\
\hline Tank/s & 48.07 & 67.01 & 75.88 & 106.19 \\
\hline Accessories & 5.00 & 2.00 & 5.00 & 2.00 \\
\hline Sub-total & 55.68 & 69.01 & 85.00 & 108.19 \\
\hline Total & 265.58 & 236.77 & 294.90 & 275.95 \\
\hline
\end{tabular}

Table 7. Weights and volume summary for a FC-only power plant using high-end current technology; net power $=$ $97.5 / 69 \mathrm{kWe}(\max / \mathrm{design})$, endurance (at max/design power) $=16 / 33 \mathrm{~min}$ with $2.61 \mathrm{~kg}$ hydrogen $(90 \mathrm{~kg}$ payload).

\section{IV.A.2. Battery-only (B-only) power plant}

Unlike fuel cells, batteries provide both extraction as well as storage. In battery design, the question is not how much battery is needed to deliver a target power but for how long can that power be sustained. For example, a high-end 45 Ah COTS cell (one of the cells in Figs 16 and 17 earlier) has a specific power of $2.08 \mathrm{~kW} / \mathrm{kg}$ and can therefore deliver $97.5 \mathrm{~kW}$ with only $46.8 \mathrm{~kg}$ of batteries. But this specific power number is applicable only for a $2 \mathrm{~s}$ discharge and hence meaningless for nominal design. Therefore, the approach followed here is to specify a target weight, along with maximum power, and then determine what cell specifications - within the constraints of the state of the art - maximize its time of operation. This iteration is carried out by trial and error at present using the battery model - not by any systematic optimization. The target weight is set to $265.08 \mathrm{~kg}$ - the total weight of the fuel cell-only power plant for $2.61 \mathrm{~kg}$ of hydrogen storage (see Tab. 7). The design is shown in the first column of Tab. 8. This design should be considered the absolute high-end of what is possible today. Weights of the battery management system and cooling system have not been considered. It is assumed that the high cell overhead $(0.6 \mathrm{~kg} / \mathrm{cell}$, from Nissan Leaf) covers for these components taking advantage of the fact that the duty cycles in aviation are comparatively trivial compared to the severe automobile requirements. 


\begin{tabular}{lccc}
\hline & Battery-only & BFC-hybrid & BFC-hybrid \\
Specifications & B30.98 & B8.30 & B4.30 \\
\hline \hline Cell, Ah & $(0.3 \mathrm{C}) 45$ & $(0.3 \mathrm{C}) 45$ & $(0.3 \mathrm{C}) 19.5$ \\
No. of units & 63 & 47 & 61 \\
Cells/unit & 3 & 1 & 1 \\
Cell wt (kg) & 0.8 & 0.8 & 0.496 \\
Cell overhead (kg) & 0.6 & 0.15 & 0.15 \\
Max P, kW & 97.5 & 30.0 & 30.0 \\
Discharge time, min & 16.33 & 13.0 & 7.2 \\
Voltage, V & $260-225$ & $195-170$ & $255-215$ \\
Cont. current, C & $2.2-3.8$ & $3.5-4.0$ & $6.0-7.0$ \\
Energy, Wh & 26.5 & 6.5 & 3.6 \\
Sp. energy, kWh/kg & 0.100 & 0.146 & 0.091 \\
Sp. power, kW/kg & 0.368 & 0.672 & 0.761 \\
Energy density, kWh/L & 0.040 & 0.039 & 0.039 \\
Weight, kg & & & \\
Volume, L & 264.6 & 44.7 & 39.4 \\
\hline
\end{tabular}

Table 8. Three lithium-ion battery designs; BX.Y: $\mathrm{X}$ is nominal energy capacity in $\mathrm{kWh}, \mathrm{Y}$ is maximum power in $\mathrm{kW}$; units are in series, cells in an unit are in parallel; discharge time and energy are for $85 \%$ discharge at max $\mathrm{P}$; operations corresponding to $\mathrm{SL} / 25^{\circ} \mathrm{C}$.

\section{IV.A.3. Battery fuel cell-hybrid (BFC-hybrid) power plant}

The approach followed in designing a battery for a BFC-hybrid power plant is similar to that followed for designing the B-only power plant earlier except that the target duration is specified (instead of weight) along with maximum power. The maximum power specified is $30 \mathrm{~kW}$ and the target durations are a minimum of 12 and 6 min respectively (up to $85 \%$ discharge). These targets are obtained from the benchmark missions described in the next section, and are meant to utilize the battery to assist during hover only. The battery designs are designated B8.30 and B4.30 and are shown in columns 2 and 3 in Tab. 8 ( 8 and 4 are the nominal energy capacities to full discharge and 30 is the maximum power).

The fuel cell power plant is re-designed for a $30 \mathrm{kWe}$ reduced maximum net power (down to $67.5 \mathrm{kWe}$ from $97.5 \mathrm{kWe}$ earlier). This amounts to a simple linear scaling for the stack and C-E weight. The other BOP weights are also assumed to scale linearly. The power electronics weight is kept the same. The reduction in fuel cell system weight is then $45 \mathrm{~kg}$.

Consider $30 \mathrm{~kW}$ power delivered for only $12 \mathrm{~min}$ (up to $85 \%$ discharge) from a lithium-ion battery. This means a nominal energy capacity of around $6 \mathrm{kWh}$. The objective is to find the minimum number of cells (to minimize battery weight) that can deliver the target power over this duration. It is found that a cell of capacity $45 \mathrm{Ah}$, maximum continuous current of at least $4 \mathrm{C}$, and of weight less than $1 \mathrm{~kg}$ (including overhead) is a minimum requirement for keeping the total power plant weight the same. This is more than what is possible COTS today, but not infeasible. For example, one of the COTS cells is available with similar specifications ( (0.3C) $45 \mathrm{Ah}, 5 \mathrm{C}$ maximum continuous current possible, though $2 \mathrm{C}$ advised) but weighs 1.5 $\mathrm{kg}$. The nominal voltage is $3.6 \mathrm{~V}$, so nominal cell capacity is $162 \mathrm{Wh}$, and nominal specific energy 0.108 $\mathrm{kWh} / \mathrm{kg}$. At $5 \mathrm{C}$ current its nominal specific power will be $0.54 \mathrm{~kW} / \mathrm{kg}$. The actual specific energy and power depend on the operating voltage, current, and depth of discharge for which the battery model is needed. A reduced weight is considered, same as the Leaf cells, which are $0.8 \mathrm{~kg} /$ cell plus a packaging overhead of 0.6 $\mathrm{kg} /$ cell, but because the required capacity of $6 \mathrm{kWh}(30 \mathrm{~kW} \times 1 / 5 \mathrm{hr})$ is $25 \%$ Leaf's capacity (24 kWh), a reduced overhead of $0.15 \mathrm{~kg} / \mathrm{cell}$ is assumed. Under these assumptions, a battery of 47 cells in series will deliver the required power for $13 \mathrm{~min}$, at $170-195 \mathrm{~V}$ (170V at $85 \%$ discharge, each cell providing around 3.6V), operate at current $3.5-4.0 \mathrm{C}$ (4.0C at $85 \%$ discharge), and weigh $44.65 \mathrm{~kg}$. This means operating at a specific power of $0.672 \mathrm{~kW} / \mathrm{kg}$ (higher than FC-only system). The specific energy depends not on operation (current drawn) but simply on capacity and weight and is $0.146 \mathrm{kWh} / \mathrm{kg}$ (significantly lower than FC-only system, as expected) for these cells. The cell volume is based on the Leaf but scaled linearly with capacity. Note that the specific power number is due to the optimistic weight assumptions (see Fig. 17 to compare technology 
level). Using COTS weight $(1.5 \mathrm{~kg} /$ cells $)$ would mean a battery weight and specific weight of $70.5 \mathrm{~kg}$ and $0.426 \mathrm{~kW} / \mathrm{kg}$ respectively. Note that this specific weight is still higher than the FC-only system for $4.12 \mathrm{~kg}$ hydrogen, but marginally, hence the benefits of hybridization will be marginal as well. As such, it weighs $44.65 \mathrm{~kg}$, just about the amount gained by reducing the fuel cell rating. Thus there is no benefit in PL. But the same PL can now be carried over a greater range as the rate of fuel consumption will be lower in hover. The design specifications are given in column 2 of Tab. 8 .

Next, consider $30 \mathrm{~kW}$ power delivered for only 6 min (up to $85 \%$ discharge) from a lithium-ion battery. This means a nominal energy capacity of around $3 \mathrm{kWh}$. It is found that a COTS cell of capacity $19.5 \mathrm{Ah}$, maximum continuous current of $18 \mathrm{C}$, and of weight $0.496 \mathrm{~kg}$ is suitable for this purpose. Considering the same overhead of $0.15 \mathrm{~kg} /$ cell, the battery weight is now $39.4 \mathrm{~kg}$. This means a small increase in PL of 5.6 $\mathrm{kg}$. The design specifications are given in column 3 of Tab. 8.

\section{IV.B. Engine charts}

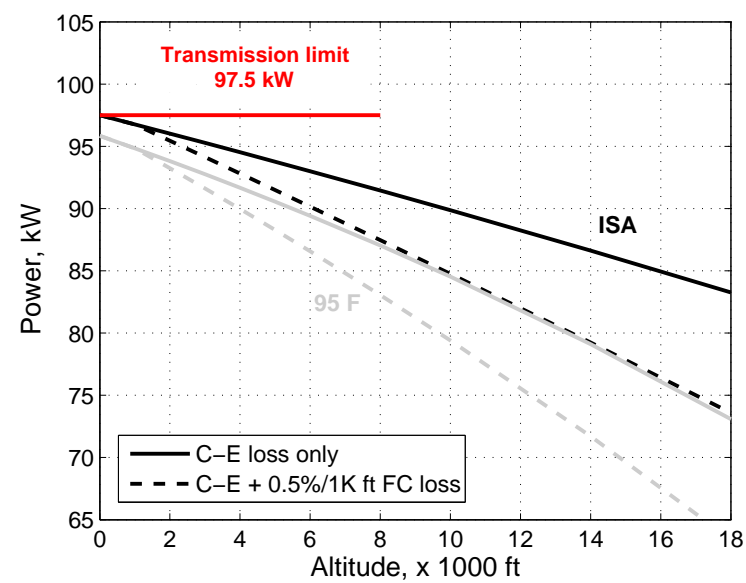

Figure 22. Maximum net power delivered vs. altitude; losses shown for two cases: Compressor/Expander loss and loss with additional fuel cell derate factor of $0.5 \%$ per $1000 \mathrm{ft}$, applied above 1000 $\mathrm{ft}$; shown for ISA and $95 \mathrm{~F}\left(35^{\circ} \mathrm{C}\right)$.

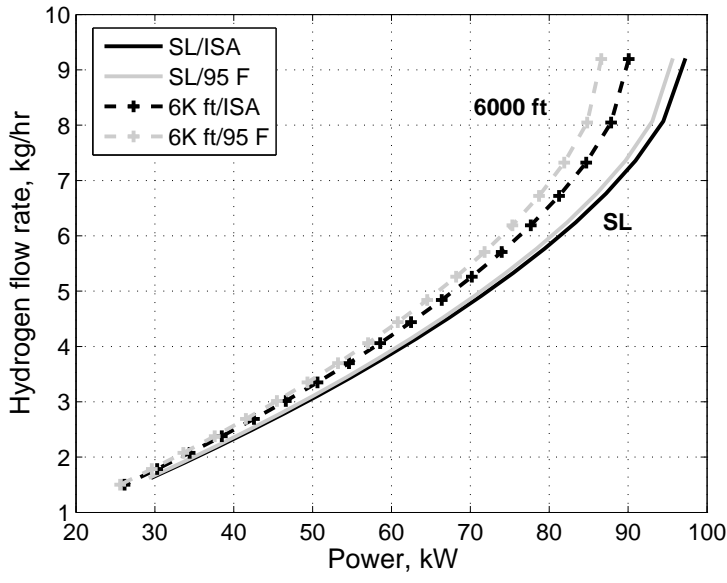

Figure 23. Hydrogen flow vs. net power available; values at altitude considers losses due to both Compressor/Expander power consumption as well as fuel cell performance degradation of $0.5 \%$ per $1000 \mathrm{ft}$, applied above $1000 \mathrm{ft}$, with altitude.

The typical engine characteristics needed for performance analysis are power vs. altitude and power vs. fuel flow. In turbo-shaft engines there is a variation of power with speed (due to ram effect in the compressor) but this effect is non-existent in piston engines, and also considered non-existent here.

The engine charts are shown for the FC-only power plant. This is because the loss of engine power with altitude is un-avoidable for a FC system and is most severe for the FC-only power plant. Batteries also undergo severe deterioration of capacity at low temperatures, but this loss can be avoided with adequate heating. For the BFC-hybrid power plant the waste heat from the stacks are assumed to contribute to this heating. The loss of engine power with altitude then stems only from the FC contribution, proportionately lesser for the BFC-hybrid power plant compared to the FC-only power plant. For the B-only power plant thermal management system must be a key component.

The engine charts are shown in Figs. 22 and 23 respectively. The power available with altitude (Fig. 22) is shown for a standard day and a $95 \mathrm{~F}$ day. The power available drops with altitude due to increasing compressor-expander (C-E) loss. As pressure drops with altitude the compressor requires more power to keep the stack pressure constant at $2 \mathrm{~atm}$. Without the stack pressure kept constant, the fuel cell will suffer dramatic losses - of the order of $5-20 \%$ in power - due to degradation of its characteristics (see Figs. 3 and 4). If the stack pressure, temperature, and humidity are maintained there should be no further loss with altitude. However, to be conservative, it is assumed that there still occurs an additional loss of $0.5 \%$ in power per $1000 \mathrm{ft}$, beyond $1000 \mathrm{ft}$. This means for a given cell current $i$, the cell voltage $v$ and power $p$ will drop by $0.5 \%$. Figure 22 shows even this amount of loss is significant, highlighting the importance of having the C-E maintain stack pressure precisely.

The fuel flow required to deliver a net power (Fig. 23) is shown at two different altitudes - SL and 6000 $\mathrm{ft}$. The maximum power in this plot are the values at SL and $6000 \mathrm{ft}$ in Fig. 22. There is greater power 
increase with flow rate in the lower power regions, i.e., an increase in power from 40 to $50 \mathrm{~kW}$ requires a 0.5 $\mathrm{kg} / \mathrm{hr}$ increase in flow rate whereas an increase from 70 to $80 \mathrm{~kW}$ requires a $1 \mathrm{~kg} / \mathrm{hr}$ increase. This is simply a reflection of the individual cell characteristic curves (Fig. 4).

\section{Performance of the All-Electric Helicopter}

The aircraft model and the power plant models are now used to calculate the performance of the allelectric helicopter. The aircraft model calculates the power required for any gross weight, speed, altitude, and temperature. The power plant model calculates the fuel flow required to supply a net power (after BOP expenses) at the same conditions. The performance analysis is limited to steady flight conditions using text book procedures. ${ }^{22}$

\section{V.A. Hover performance}

From power required to hover and the maximum power available at any altitude, the hover ceiling is calculated. Because altitude losses are most severe for the FC-only power plant, the hover performance is shown for this power plant only.

The hover ceiling is shown in Fig. 24. With a maximum GTOW of $622 \mathrm{~kg}$, the helicopter can hover at only up to around $7200 \mathrm{ft}$ on a standard day and at around $4900 \mathrm{ft}$ on a hot $95 \mathrm{~F}$ day (for reference: Yellowstone National Park $=6650 \mathrm{ft}$, Mexico City $=7400 \mathrm{ft}$ ). Below these altitudes the excess power can be used to climb. For a GTOW of $622 \mathrm{~kg}$, the rate-of-climb variation with altitude is shown in Fig. 25. The rate of climb goes to zero at the altitudes that are the hover ceilings in Fig. 24.

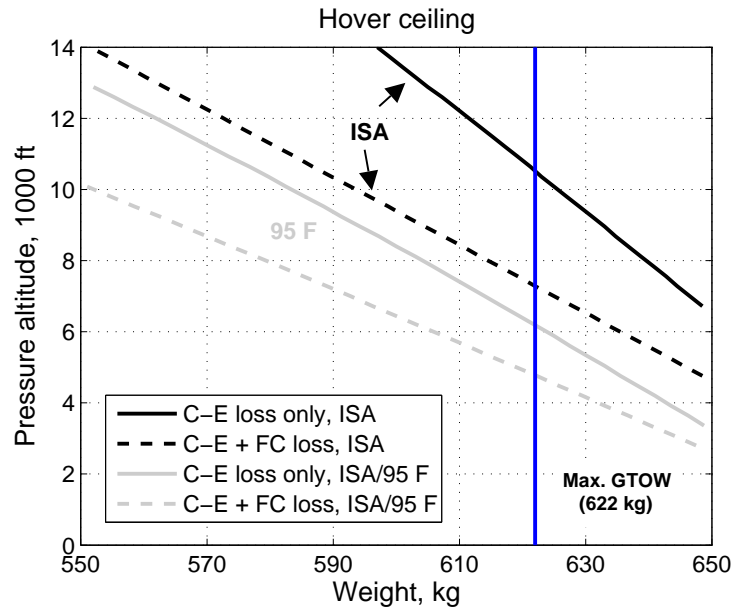

Figure 24. Hover ceiling; based on the two cases of power loss due to $\mathrm{C} / \mathrm{E}$ only and $\mathrm{C} / \mathrm{E}$ plus fuel cell..

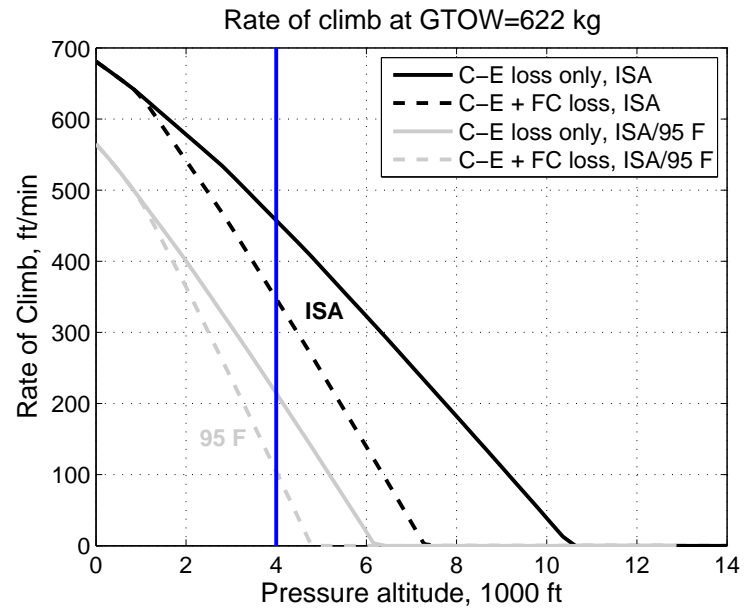

Figure 25. Hover rate of climb vs. altitude for GTOW=622 kg.

\section{V.B. Cruise performance}

All cruise performances are calculated using engine losses from both C-E and FC degradation. During cruise, the FC alone is meant to provide the entire power, regardless whether FC-only or BFC-hybrid power plant is used. The payload-range plot remains unaffected by battery assist as power during best range speed $\left(V_{b r}\right)$ is delivered entirely by the fuel cell. Therefore, all results in this subsection are shown for the FC-only power plant.

The rate of climb in cruise is shown in Fig. 26. There is substantial drop in rate of climb with altitude and temperature below $80 \mathrm{kt}$ speed due to substantial drop in engine power. The fuel flow required corresponding to the power required are shown in Fig. 27. The fuel flow is almost proportional to the power required (see Fig. 23 earlier) at lower power but increases substantially at higher power. Conventionally $1.05 \%$ of fuel flow is considered to account for engine degradation but hydrogen being expensive and this being an specialty engine that is not done here. At each speed, speed $(\mathrm{km} / \mathrm{hr})$ divided by the fuel flow $(\mathrm{kg} / \mathrm{hr})$ gives specific range (SR), i.e., distance covered by unit fuel in $\mathrm{km} / \mathrm{kg}$. The speed corresponding to maximum SR is the best range speed. Conventionally, the $99 \%$ of maximum SR on the higher speed side of the maximum is used 


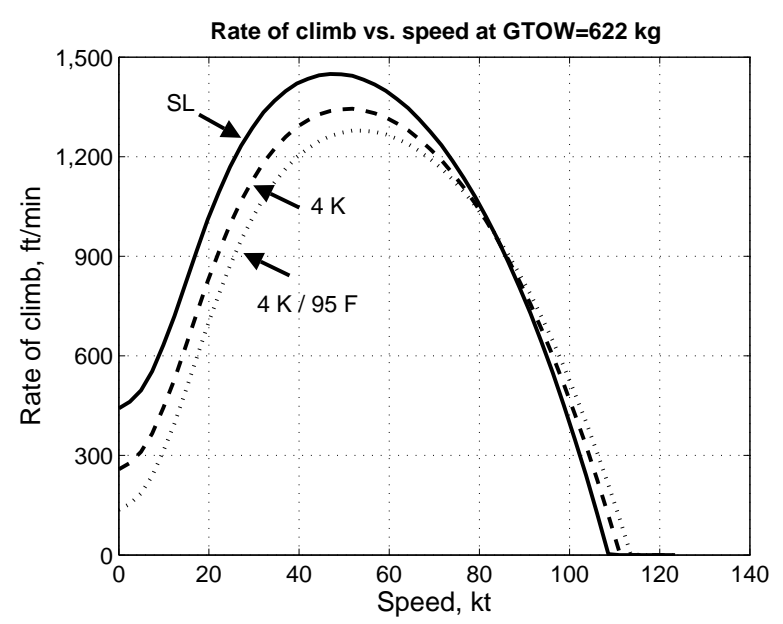

Figure 26. Rate of climb for maximum GTOW of 622 $\mathrm{kg}$ at $\mathrm{SL} / \mathrm{ISA}, 4 \mathrm{~K} \mathrm{ft} / \mathrm{ISA}$, and $4 \mathrm{~K} \mathrm{ft} / 95 \mathrm{~F}$.

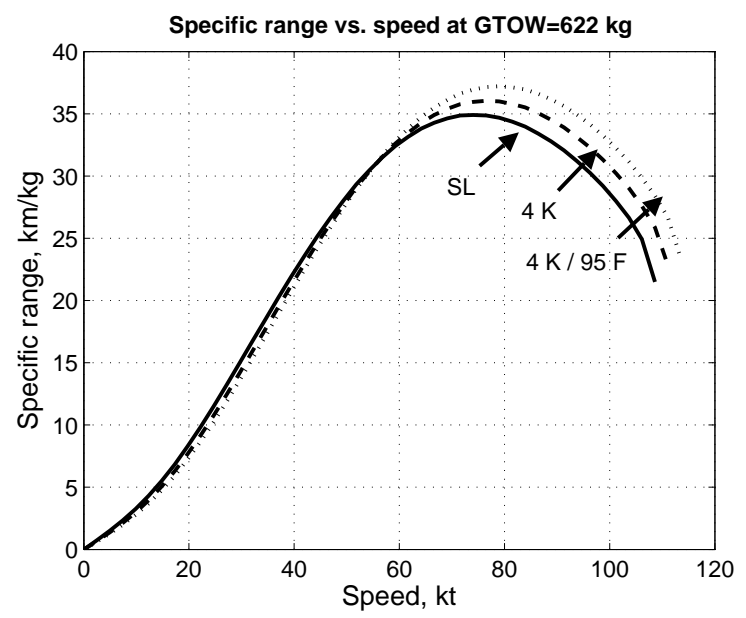

Figure 28. Specific range for maximum GTOW of 622 $\mathrm{kg}$ at $\mathrm{SL} / \mathrm{ISA}, 4 \mathrm{~K} \mathrm{ft} / \mathrm{ISA}$, and $4 \mathrm{~K} \mathrm{ft} / 95 \mathrm{~F}$.

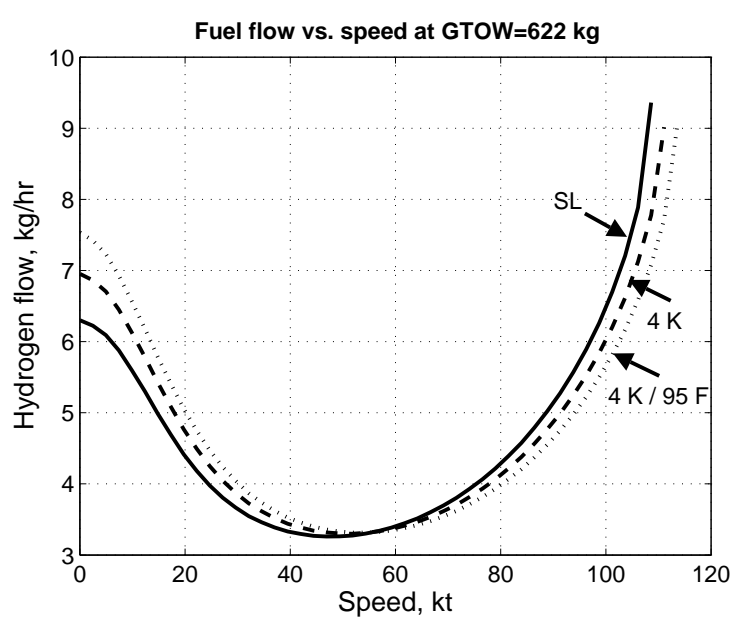

Figure 27. Engine fuel flow for maximum GTOW of $622 \mathrm{~kg}$ at SL/ISA, $4 \mathrm{~K} \mathrm{ft} / \mathrm{ISA}$, and $4 \mathrm{~K} \mathrm{ft} / 95 \mathrm{~F}$.

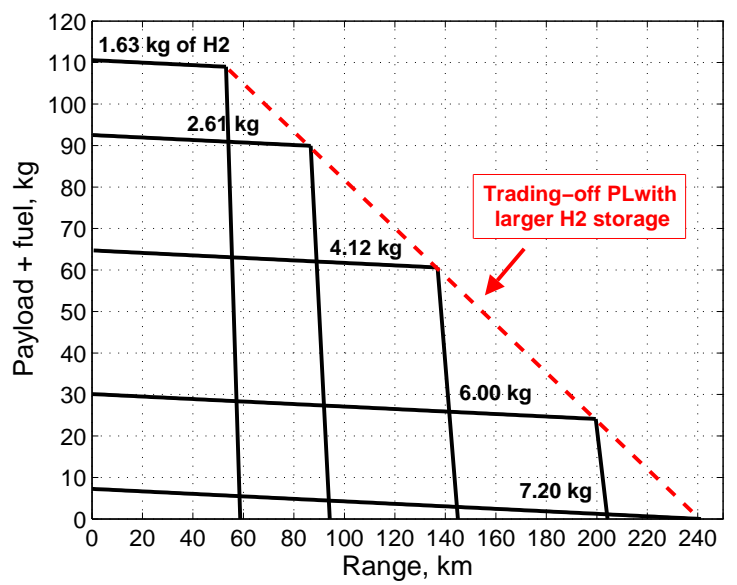

Figure 29. Payload vs. range at SL/ISA with several fuel storage levels (only 1.63 and $2.61 \mathrm{kgs}$ applicable to manned missions).

to determine the best range speed. Figure 28 shows SR at SL/ISA, $4 \mathrm{~K} \mathrm{ft} / \mathrm{ISA}$, and $4 \mathrm{~K} \mathrm{ft} / 95 \mathrm{~F}$. The SR varies with gross weight, so as fuel is burned (and exhaust water/vapor discarded) and gross weight reduces, SR increases. But this is a small effect for a hydrogen helicopter because the carried fuel will always be significantly lower compared to gasoline (about 4-6 times lower for the same energy content, due to high calorific value of hydrogen and higher efficiency of a fuel cell). The main weight is the weight of storage tanks and accessories which obviously cannot be discarded during the mission. Due to these reasons the payload-range curve is flat compared to a conventional fuel.

The payload-range curve at SL/ISA is shown in Fig. 29. Recall, the original payload cannot be flown at any fuel level (since increase in weight from new engine is greater than original fuel weight). But $71 \%$ of the original payload can be flown $(109 \mathrm{~kg})$. This will allow only $1.63 \mathrm{~kg}$ of fuel however, with which a distance (one-way) of only $60 \mathrm{~km}$ can be covered. An important difference between the new hydrogen helicopter and the old conventional one is that carrying less fuel allows neither any meaningful increase in payload nor increase in range. Both the horizontal and vertical lines of the payload-range curve are steep. The horizontal line is steep because the new fuel packs a lot of energy and a small amount is all that is needed. Thus carrying less fuel does not allow any substantial increase in payload. The vertical line is steep because it is the tank that is heavy, not the fuel, and since set by design once for all cannot be traded for PL even if desired. Thus carrying less fuel does not allow any substantial increase in range. This leads to a key conclusion that the fuel system of a hydrogen helicopter must be designed based on a different paradigm. Depending on the mission, the right size tank will be fit-in, one that is best suited for the mission. The vertical lines in the payload-range curve are less important, the line that joins the ends of the full-tank range 
points is more important.

The range in the payload-range plot gives the maximum range possible under the ideal condition of continuous flight at best range speed. For realistic range and duration of flight a detailed mission analysis is required.

\section{V.C. Mission Analysis}

\section{V.C.1. Three benchmark missions}

We propose three benchmark missions as shown in Fig. 30. The first mission is simplest, meant only for an initial technology demonstrator. It includes only 6 min of hover. The second and third missions are relatively more realistic. Both of these missions contain 11 minutes of hover. The second mission is considered a nominal operation. The third mission is hot and high $(4 \mathrm{~K} \mathrm{ft} / 95 \mathrm{~F})$.

The first mission contains two segments of hover with cruise in-between. The second mission begins with hover, then climb to cruise altitude, then cruise at best range speed, followed by descent at minimum power speed, and finally ends with hover. The hover segments are considered moderately high/hot. The climb, cruise, and descent are as per ISA. From hover to climb and then from descent to hover, it is assumed that conditions change abruptly between $3 \mathrm{~K} / 30^{\circ} \mathrm{C}$ and ISA. The cruise is in level flight - no gradual descent allowed. The descent has no range credit, so best done in minimum power speed. The second mission, being entirely at $4 \mathrm{~K} \mathrm{ft} / 95 \mathrm{~F}$, does not have climb or descent segments. All missions contain take-off and landing segments of 2 min each where thrust is assumed to be $50 \%$ GTOW.

V.C.2. Performance with B-only, FC-only, and BFC-hybrid power plants

The performance of the all-electric helicopter for the three benchmark missions are summarized in Tabs. 9, 10 and 11. All missions carry an emergency reserve of $0.38 \mathrm{~kg}$ of hydrogen (23\%-5\% of total fuel corresponding to $1.63-7.20 \mathrm{~kg}$ of fuel). This corresponds to $3 \mathrm{~min}$ of hover $\left(3 \mathrm{~K} / 30^{\circ} \mathrm{C}\right)$ or $13.8 \mathrm{~min}$ of

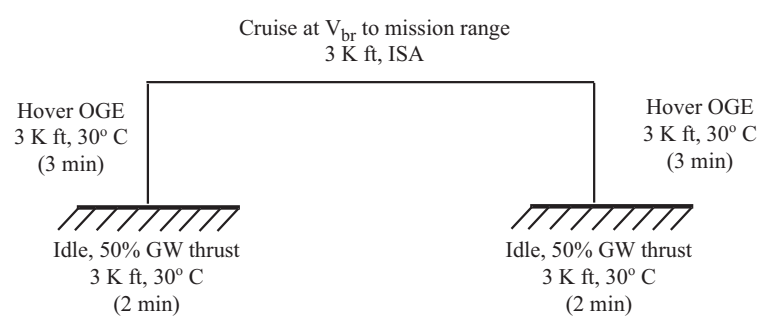

(a) Mission 1, simple

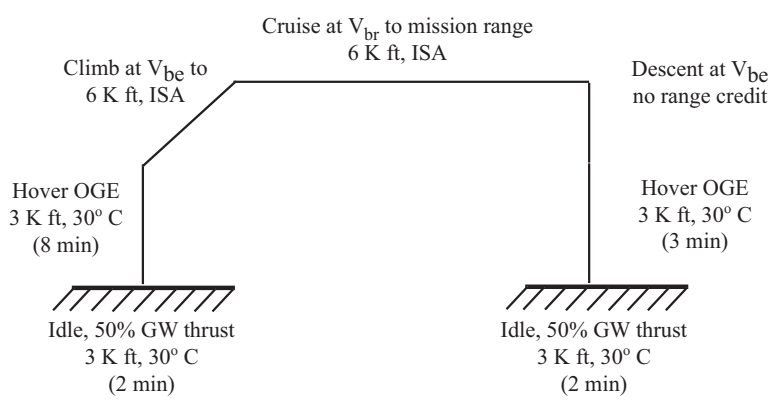

(b) Mission 2, nominal.

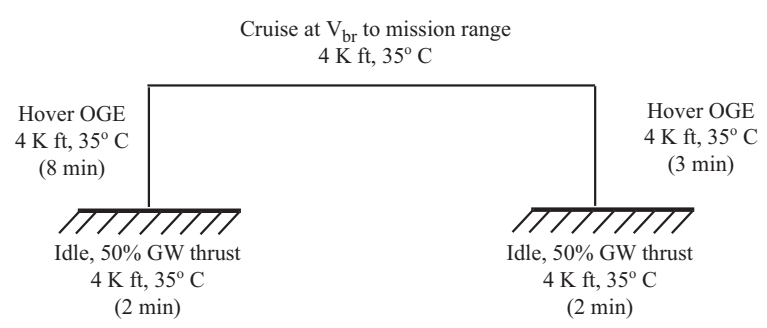

(c) Mission 3, hot/high.

Figure 30. Three missions for a light-utility manned allelectric helicopter. cruise $(3 \mathrm{~K} / \mathrm{ISA})$. These are not reserves in the conventional sense, but minimal backups to cover for unforeseen losses. A mission is considered feasible only when a non-zero climb or cruise segment is possible. With $7.2 \mathrm{~kg}$ of hydrogen, no PL can be flown, but is considered only to obtain a theoretical limit of range.

Consider mission 1 performance (Tab. 9). Of particular interest is the manned mission flown with $90 \mathrm{~kg}$ of PL. For this mission all three types of power plants, B-only, FC-only, and BFC-hybrid can be compared consistently. With the B-only power plant (using B30.98, Tab. 8) a total flight time of 16.5 min can be achieved (ignoring $4 \mathrm{~min}$ on ground). Out of these, $6 \mathrm{~min}$ are in hover, so the range is limited to only 25.8 $\mathrm{km}$. With the FC-only power plant this mission requires $2.61 \mathrm{~kg}$ of hydrogen tank. A total flight time of $25 \mathrm{~min}$ can be achieved with a range of $44.2 \mathrm{~km}$. With the BFC-hybrid power plant (using B4.30, Tab. 8) this mission again requires $2.61 \mathrm{~kg}$ of hydrogen tank. But a total flight time of 30 min can now be achieved with a range of $55.8 \mathrm{~km}$. The PL is also slightly increased by $5.6 \mathrm{~kg}$. Nonetheless, all three power plants have poor performances. And given the variety of technology factors and assumptions that went into their design it is premature to conclude that the FC-only power plant is superior to the B-only power plant. It is 


\begin{tabular}{cccccc}
\hline $\begin{array}{c}\mathrm{H}_{2} \\
(\mathrm{~kg})\end{array}$ & $\begin{array}{c}\text { Range } \\
(\mathrm{km})\end{array}$ & $\begin{array}{c}\text { Payload } \\
(\mathrm{kg})\end{array}$ & $\begin{array}{c}\text { Duration } \\
(\mathrm{min})\end{array}$ & $\begin{array}{c}\text { Cruise time } \\
(\mathrm{min})\end{array}$ & $\begin{array}{c}\text { Energy } \\
(\mathrm{kWh})\end{array}$ \\
\hline \hline & & \multicolumn{5}{c}{ B-only } & & \\
- & 25.8 & 90 & 20.5 & 10.5 & 27 \\
& & & & & \\
& & & FC-only & & \\
1.63 & 9.3 & 109 & 14 & 4 & 16 \\
2.61 & 44.2 & 90 & 29 & 19 & 31 \\
4.12 & 99.9 & 60 & 53 & 43 & 54 \\
6.00 & 167.3 & 24 & 82 & 72 & 82 \\
7.20 & 209.1 & 0 & 100 & 90 & 100 \\
& & & & & \\
& & & $\mathrm{BFC}$ & & \\
1.63 & 20.9 & 114.6 & 19 & 9 & 20 \\
2.61 & 55.8 & 95.6 & 34 & 24 & 36 \\
4.12 & 111.5 & 65.6 & 58 & 48 & 59 \\
6.00 & 178.9 & 29.6 & 87 & 77 & 88 \\
7.20 & 223.1 & 5.6 & 106 & 96 & 106 \\
\hline
\end{tabular}

Table 9. Analysis of mission 1 with battery-only (B-only), fuel cell-only (FC-only) and battery fuel cell-hybrid (BFC) power plants (all missions carry reserve fuel worth $3 \mathrm{~min}$ of hover at $3 \mathrm{~K} / 30 \mathrm{C}$ or $13.8 \mathrm{~min}$ of cruise at $3 \mathrm{~K} / \mathrm{ISA}$ ).

\begin{tabular}{cccccc}
\hline $\begin{array}{c}\mathrm{H}_{2} \\
(\mathrm{~kg})\end{array}$ & $\begin{array}{c}\text { Range } \\
(\mathrm{km})\end{array}$ & $\begin{array}{c}\text { Payload } \\
(\mathrm{kg})\end{array}$ & $\begin{array}{c}\text { Duration } \\
(\mathrm{min})\end{array}$ & $\begin{array}{c}\text { Climb+Cruise } \\
(\mathrm{min})\end{array}$ & $\begin{array}{c}\text { Capacity } \\
(\mathrm{kWh})\end{array}$ \\
\hline \hline & & & FC-only & & \\
1.63 & - & 109 & - & - & - \\
2.61 & 13.1 & 90 & 23.5 & $3+2.5$ & 27 \\
4.12 & 67.1 & 60 & 46 & $3+25$ & 49 \\
6.00 & 136.7 & 24 & 75 & $3+54$ & 76 \\
7.20 & 179.9 & 0 & 93 & $3+72$ & 94
\end{tabular}

$\mathrm{BFC}$

\begin{tabular}{cccccc}
1.63 & - & 109 & - & - & - \\
2.61 & 19.2 & 90 & 30 & $12+0$ & 32 \\
4.12 & 64.8 & 60 & 49 & $12+19$ & 52 \\
6.00 & 120.0 & 24 & 72 & $12+42$ & 72 \\
7.20 & 156.0 & 0 & 87 & $12+57$ & 88 \\
\hline
\end{tabular}

Table 10. Analysis of mission 2 with fuel cell-only (FC-only) and battery fuel cell-hybrid (BFC) power plants (all missions carry reserve fuel worth $3 \mathrm{~min}$ of hover at $3 \mathrm{~K} / 30 \mathrm{C}$ or $13.8 \mathrm{~min}$ of cruise at $3 \mathrm{~K} / \mathrm{ISA}$ ). 
concluded however that the BFC-hybrid is superior to either B-only or FC-only power plant alone. Given that the technology factors and assumptions are the same between the hybrid and the stand alone designs, this conclusion is valid. For this mission, the hybrid power plant doubles the range and endurance from a B-only power plant. Henceforth, for missions 2 and 3 only the FC-only and BFC-hybrid power plants are considered.

\begin{tabular}{cccccc}
\hline $\begin{array}{c}H_{2} \\
(\mathrm{~kg})\end{array}$ & $\begin{array}{c}\text { Range } \\
(\mathrm{km})\end{array}$ & $\begin{array}{c}\text { Payload } \\
(\mathrm{kg})\end{array}$ & $\begin{array}{c}\text { Duration } \\
(\mathrm{min})\end{array}$ & $\begin{array}{c}\text { Cruise time } \\
(\mathrm{min})\end{array}$ & $\begin{array}{c}\text { Capacity } \\
(\mathrm{kWh})\end{array}$ \\
\hline \hline & & & FC-only & & \\
1.63 & - & 109 & - & - & - \\
2.61 & 19.2 & 90 & 23 & 8 & 27 \\
4.12 & 75.6 & 60 & 47 & 32 & 49 \\
6.00 & 146.4 & 24 & 76 & 61 & 77 \\
7.20 & 189.6 & 0 & 94 & 79 & 94 \\
& & & & & \\
& & & BFC & & \\
1.63 & 11.0 & 109 & 19.6 & 4.6 & 24 \\
2.61 & 47.0 & 90 & 34.6 & 19.6 & 39 \\
4.12 & 103.2 & 60 & 58.0 & 43.0 & 61 \\
6.00 & 174.0 & 24 & 87.5 & 72.5 & 89 \\
7.20 & 218.4 & 0 & 106 & 91.0 & 106 \\
\hline
\end{tabular}

Table 11. Analysis of mission 3 with fuel cell-only (FC-only) and battery fuel cell-hybrid (BFC) power plants (all missions carry reserve fuel worth $3 \mathrm{~min}$ of hover at $3 \mathrm{~K} / 30 \mathrm{C}$ or $13.8 \mathrm{~min}$ of cruise at $3 \mathrm{~K} / \mathrm{ISA}$ ).

Consider mission 2 performance (Tab. 10). Mission 2 is special because of its climb segment. With the FC-only power plant, the climb segment is flown at $V_{b r}$ with a climb rate of $1000 \mathrm{ft} / \mathrm{min}$. The power required during this segment is similar to that needed for hover. With the BFC-hybrid power plant this segment must be flown differently. The BFC-hybrid power plant (using B8.30, Tab. 8) allows power assist for around 12 min only. Hence the power plant can provide battery assist only in hover, during cruise the FC must provide the full power all by itself. The climb segment is therefore flown at $V_{b e}$ to achieve the best climb rate. A climb rate of $250 \mathrm{ft} / \mathrm{min}$ is used, which means $12 \mathrm{~min}$ of climb to reach $6 \mathrm{~K} \mathrm{ft}$. Because $V_{b e}$ is flown instead of $V_{b r}$, the distance covered during this segment is reduced. There is a significant difference between the two speeds (see Fig. 2). In addition, more fuel is burned during this segment (due to the slower climb) compared to the FC-only power plant, which contributes to further reduction in range. Only for the $90 \mathrm{~kg}$ PL case does the BFC-hybrid power plant show a greater range. But this is only because the FC-only power plant cannot even fly a 12 min cruise. Note that both the FC-only and BFC-hybrid power plants can fly this mission for $90 \mathrm{~kg}$ PL and lower only. The $109 \mathrm{~kg}$ payload cannot be flown - the aircraft will not have enough fuel for the climb and cruise segments.

Consider mission 3 performance (Tab. 11). Even though hot and high, this mission has no climb segment. The battery specification for the BFC-hybrid power plant is same as that of mission 2 (B8.30, Tab. 8). As in mission 2, the FC-only power plant can fly this mission for only $90 \mathrm{~kg}$ PL and lower, but the BFC-hybrid power plant saves enough fuel from battery assist to fit in a $109 \mathrm{~kg}$ PL mission. The PL and duration of flight for mission 3 are plotted vs range in Fig. 31 for both the FC-only and BFC power plants. The advantage of using a hybrid system is clear. Regardless of the range, the hover duration is fixed, and because the battery is active only during hover, the curves show a constant increment. Note that the PL line correspond to the hydrogen storage line shown in Fig. 29 earlier.

The power profiles of the three missions for $90 \mathrm{~kg}$ PL using the FC-only power plant are summarized in Fig. 32. They are the same for B-only, FC-only, and BFC-hybrid systems, except for mission 2 for which the BFC-hybrid power profile is different (due to the slow climb). 


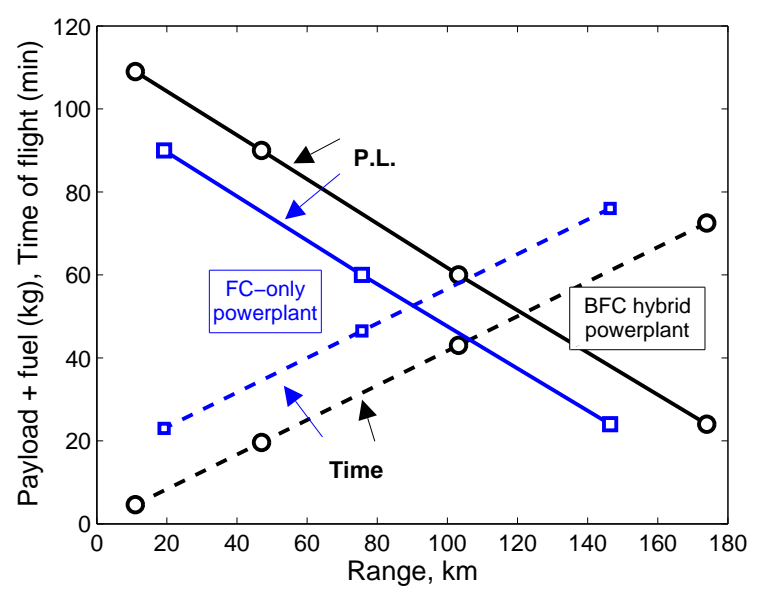

Figure 31. Mission 3 performance compared between fuel cell-only (FC-only) and a battery fuel cell-hybrid (BFC-hybrid) power plants.

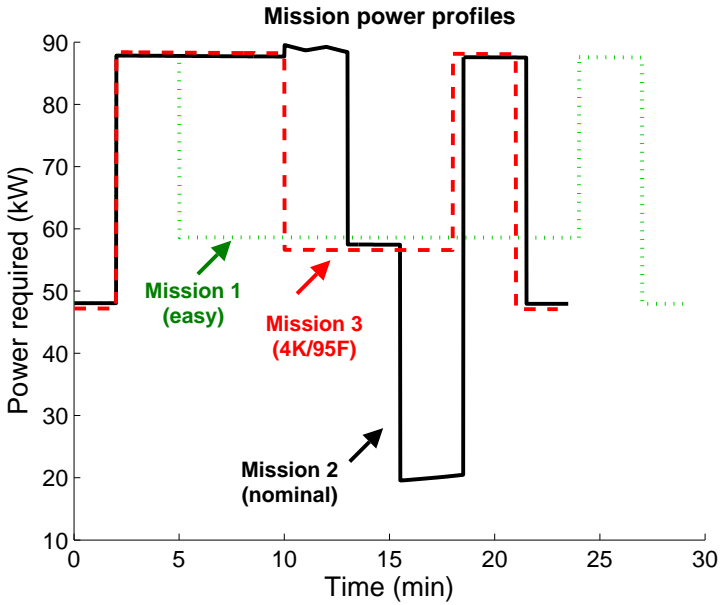

Figure 32. Power profiles of the three missions flown with $2.61 \mathrm{~kg}$ hydrogen tanks; $90 \mathrm{~kg} \mathrm{PL}$, reserve fuel for $3 \mathrm{~min}$ of hover at $3 \mathrm{~K} / 95 \mathrm{~F}$ or $13.8 \mathrm{~min}$ cruise at 3K/ISA.

\section{Technology Status and Future Requirements}

The technology status of the present all-electric power plant is best described by locating it on the state of the art in rotorcraft engines. The state of the art data is taken from Ref. 23 but modified into a form suitable for such a comparison. Normally, the brake specific fuel consumption (BSFC) and specific power (SP) form suitable measures for comparing engines. The comparison of BSFC is primarily a comparison of engine efficiency provided the same fuel is used. The fuel is dramatically different here. Hence instead of BSFC, the fraction of fuel calorific value extracted by the engine is compared. To this end the BSFC is first used to calculate (1/BSFC)/(calorific value of fuel) and then this value is compared. The calorific value of conventional fuel is assumed to be $13 \mathrm{kWh} / \mathrm{kg}$ (gasoline). The calorific value of hydrogen is $39 \mathrm{kWh} / \mathrm{kg}$ (same as that used to calculate stack efficiency). The specific power measure remains the same.

The efficiencies and specific power are shown in Figs. 33 and 34 respectively. The all-electric engine shown is the FC-only engine. Because all three engine types (B-only, FC-only, and BFC-hybrid) have nominally the same engine weight (for the common $90 \mathrm{~kg}$ PL case) and the same maximum power, the specific power plot is generic. The efficiency plot is relevant only for a fuel based power plant and so comparing the FC-only engine is appropriate. The benefit of using a fuel cell is clear from Fig. 33. Note that this is not contaminated with the benefit of using hydrogen as fuel - that has been factored out by normalizing with the fuel calorific value. This is the efficiency with which the fuel cell system delivers net power. Note also that this is a different measure from the stack efficiency $\eta_{f}$ in that this efficiency is related to net power after BOP expenses. Obviously the value is dependent on power level (because BSFC depends on fuel flow which depends on power level). Values at two levels are shown, one corresponding to maximum power and another corresponding to cruise power. The efficiency of the former is lower as the fuel cell operates at a lower voltage (hence low stack efficiency) and higher fuel flow (hence greater C-E loss) conditions.

The extremely poor state of specific power is shown in Fig. 34. This is not surprising however. Note that the specific power of the original aircraft engine is at best $108 / 117=0.92 \mathrm{~kW} / \mathrm{kg}(108 \mathrm{~kW}$ is maximum power before derated and $117 \mathrm{~kg}$ is the engine dry weight only). The specific power value falls near the 1940s/50s piston engine data - which were similar to automobile engines in weight. Current piston engine data are close to these values - the R 22 original engine is shown for reference. Basing the design on component technologies which are beginning to compete with automobile state of the art is expected to produce such a result. However, the curve forms a suitable quantitative basis for setting requirements for the future. The objective of such requirements is to motivate break-through innovations that will bring the state of the art closer not only to piston engines but also to turbo-shafts.

The gap in specific power is considerable to bridge. A potential bypass would be an innovative drive system that is enabled by the electric power plant. For example, the current transmission weighs approximately $60-90 \mathrm{~kg}$. This is a significant amount of weight which if saved would reduce requirements for specific power. Suggested technology targets for future are summarized in Tab. 12. The motor and drive system are 


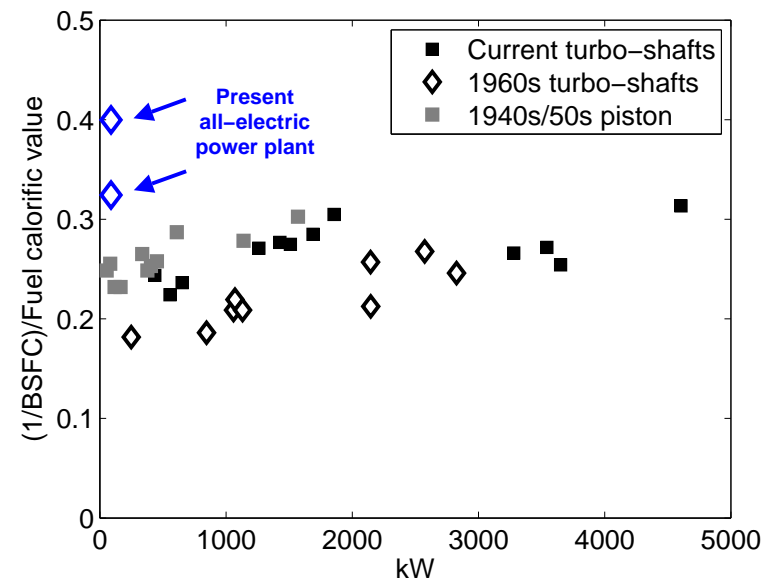

Figure 33. Comparison of present all-electric engine with the state of the art in rotorcraft combustion engines based on fraction of fuel calorific value extracted.

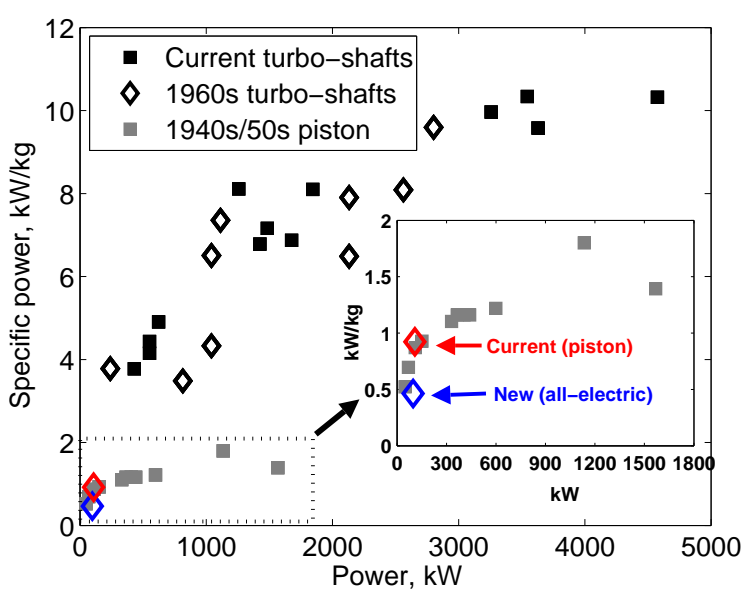

Figure 34. Comparison of present all-electric engine with the state of the art in rotorcraft combustion engines based on specific power.

considered together as one unit.

\section{Conclusions}

This paper carried out a conceptual design of an all-electric power plant for use in an ultra-light manned helicopter. The objectives were to assess status of current technology of the key components of the power plant, identify barriers generic to aviation and unique to rotorcraft, and set future targets in each discipline required to achieve performance comparable to current combustion engines. The approach was to carry out a paper conversion of a R 22 Beta II-like helicopter from its piston engine to a Lithium ion battery Proton Exchange Membrane fuel cell-hybrid power plant and then carry out performance studies of the all-electric aircraft. The focus was on the power plant, the aircraft was assumed to remain the same.

First, an analysis of the R 22 Beta II-like rotorcraft was performed to establish its power requirements. Then, all major components of the all-electric power plant were designed and synthesized into an engine model. At this stage the technology status of each component was reviewed using gross performance and sizing as the key metrics for assessment. Three engine models were synthesized - battery-only, fuel cell-only, and battery fuel cell-hybrid. The engine models were then used to carry out performance studies for hover and cruise. Three benchmark missions were proposed for the assessment of all all-electric rotorcraft and the performance of each of the three engine models were studied for these missions. The gross performance of these models were compared with the state of the art in rotorcraft combustion engines - piston engines and turbo-shafts. Based on this study, three key conclusions are drawn. Note that these conclusions are to be considered in the context of the power level $(100 \mathrm{~kW})$ and the weight class $(650 \mathrm{~kg})$ considered in this study.

1. If the best possible (highest-end) combination of automobile EV technologies are brought to bear on aviation, the status of specific power for electric propulsion will now be approximately comparable to 1940s and 50s rotorcraft piston engines and half of the current R 22 Beta II-like piston engines. However, fuel efficiency (normalized to calorific values of gasoline and hydrogen as per case) is almost twice that of piston engines. Specifically, for the R 22 Beta II helicopter, keeping hover ceiling in SL/ISA same means original payload can no longer be flown. But $60-70 \%$ of the original payload $(90-109 \mathrm{~kg})$ can be flown, and the flight duration and range under these conditions are approximately $30 \mathrm{~min}$ including 12 minutes of hover (plus $3 \mathrm{~min}$ worth of hover reserve) and $45 \mathrm{~km}$ under high/hot $(4 \mathrm{~K} \mathrm{ft} / 95 \mathrm{~F})$ conditions.

2. Batteries are superior for hover ceiling with adequate temperature control. Fuel cells are superior for cruise range with adequate pressure control. A combination of the two, with fuel cells designed for cruise and batteries designed for power assist during hover, appears to be the optimum solution with current technology. (This is precisely what was carried out by the Boeing fuel cell demonstrator airplane and the same conclusion carries over to rotorcraft because the power differences here are even 


\begin{tabular}{|c|c|c|c|}
\hline Technology & Present & Near term $(5$ yr $)$ & Long term (10-15 yr) \\
\hline \multicolumn{4}{|l|}{ FUEL CELL } \\
\hline cell $i_{c}-v_{c}, \mathrm{~A} / \mathrm{cm}^{2}-\mathrm{V}$ & $0.35-0.65$ & $0.6-0.75$ & $0.7-0.8$ \\
\hline Sp. P, kW/kg & 1.47 & 2.0 & 3.0 \\
\hline $\mathrm{P}$ ds., kW/L & 1.75 & 2.0 & 4.0 \\
\hline Sp. P (w BOP), kW/kg & 0.65 & 1.5 & 3.0 \\
\hline P. ds. (w BOP), kW/L & 0.68 & 1.0 & 2.0 \\
\hline \multicolumn{4}{|c|}{ COMPRESSOR-EXPANDER } \\
\hline Flow rate, $\mathrm{kg} / \mathrm{s}$ & 0.11 & 0.20 & 0.30 \\
\hline Sp. P, kW/kg & 0.65 & 2.0 & 3.0 \\
\hline $\mathrm{P}$ ds., kW/L & 1.0 & 1.0 & 1.5 \\
\hline Efficiency & 0.6 & 0.8 & 0.85 \\
\hline \multicolumn{4}{|l|}{ H2 STORAGE } \\
\hline $\mathrm{H} 2$ gas wt $\%$ & 0.054 & 0.075 & 0.15 \\
\hline $\mathrm{H} 2$ gas vl, $\mathrm{kg} / \mathrm{L}$ & 0.038 & 0.075 & 0.10 \\
\hline $\mathrm{H} 2$ liq wt $\%$ & 0.055 & 0.075 & 0.15 \\
\hline $\mathrm{H} 2$ liq vl, $\mathrm{kg} / \mathrm{L}$ & 0.040 & 0.075 & 0.10 \\
\hline Amount, $\mathrm{kg}$ & $4-5$ & $7-10$ & $10-15$ \\
\hline \multicolumn{4}{|l|}{ BATTERY } \\
\hline Capacity, Ah & $20-45$ & $55-75$ & 100 \\
\hline Max cont.I, $\mathrm{C}$ & $3-5$ & 5 & 5 \\
\hline Sp. $\mathrm{P}, \mathrm{kW} / \mathrm{kg}$ & 0.7 & 2.5 & 5.0 \\
\hline Sp. E, kWh/kg & $0.10-0.15$ & $0.2-0.3$ & 1.0 \\
\hline E. ds., kWh/L & 0.04 & 0.25 & 0.75 \\
\hline \multicolumn{4}{|c|}{ ELECTRIC MOTOR \& DRIVE } \\
\hline Max cont. $\mathrm{P}, \mathrm{kW}$ & 93 & 250 & 1000 \\
\hline Sp. P, kW/kg & 0.75 & $2-5$ & $5-8$ \\
\hline $\mathrm{P}$ ds., kW/L & 5.0 & 5.0 & 5.0 \\
\hline Efficiency & 0.93 & 0.95 & 0.95 \\
\hline Min speed, RPM & 2500 & 1000 & 500 \\
\hline Max torque, $\mathrm{Nm}$ & 500 & 2000 & 8000 \\
\hline
\end{tabular}

Table 12. Technology levels for hydrogen helicopter propulsion system; assumed in present study, near term requirements (piston engine targets), long term requirements (turbo-shaft engine targets); P: power, E: energy, ds.: density, Sp.: specific; Min speed and Max torque correspond to max power.

greater due to hover.)

3. An unique barrier to all-electric propulsion in rotorcraft is its high torque-low RPM rotor operation. This is different, by an order of magnitude, from what is considered high torque-low RPM in the electric motor world. For example, for the R 22 Beta II-like helicopter, torque-RPM is approximately 2000 Nm-510 whereas the Honda Clarity 2009 electric motor can operate at most at $250 \mathrm{Nm}-4000$ at the highest power. The transmission is an unique and major component in rotorcraft, and as such presents an unique opportunity. An effective way to bypass the limitations of the power plant would be to design an electric drive that can remove the need for a transmission. 


\section{References}

${ }^{1}$ International Energy Agency, "Electric and Plug-in Hybrid Electric Vehicles Roadmap," Directorate of Sustainable Energy Policy and Technology (SPT), June 2011.

${ }^{2}$ U.S. Department of Energy, "FY2010 Progress Report For the DOE Hydrogen Program," DOE/GO-102011-3178, February 2011.

${ }^{3}$ Lapena-Rey, N. et al., "Environmentally Friendly Power Sources for Aerospace Applications," Journal of Power Sources, Vol. 181, No. 2, July 2008, pp. 353-362.

${ }^{4}$ Lapena-Rey, N. et al., "First Fuel-Cell Manned Aircraft," Journal of Aircraft, Vol. 47, No. 6, November-December 2010, pp. $1825-1835$.

${ }^{5}$ Johnson, W., Helicopter Theory, Dover Publications, Inc., New York, 1994.

${ }^{6}$ Datta, A. and Chopra, I., "Validation and Understanding of UH-60A Vibratory Loads in Steady Level Flight,", Journal of the American Helicopter Society, Vol. 49, No. 3, July 2004, pp. 271-287.

${ }^{7}$ R22 Pilot's Operating Handbook and FAA Approved Rotorcraft Flight Manual, RTR 061, Robinson Helicopter Co., Torrance, CA, December 23, 2009.

${ }^{8}$ Chretien, P., "The Quest for the World's First Electric Manned Helicopter Flight," VERTIFLITE, Vol. 58, No. 2, March/April 2012, pp. 38-42.

${ }^{9}$ Schneider, D., "Helicopters Go Electric," IEEE Spectrum, Vol. 49, No. 1, January 2012, pp. 11-12.

${ }^{10}$ Matsunaga, M., Fukushima, T. and Ojima, K., "Powertrain System of Honda FCX Clarity Fuel Cell Vehicle," World Electric Vehicle Journal, Vol. 3, 2009; Following Int. Battery, Hybrid and Fuel Cell Electric Vehicle Symposium 24, Stavanger, Norway, May 13-16, 2009.

${ }^{11}$ Barbir, F., PEM Fuel Cells Theory and Practice, Elsevier Academic Press, 2005.

${ }^{12}$ Spiegel, C. S., Designing and Building of Fuel Cells, McGraw-Hill, First ed., 2007.

${ }^{13}$ O'Hayre, R., Cha, S., Colella, W. and Prinz, F. B., Fuel Cell Fundamentals, John Wiley and Sons, Inc., Second Ed., 2009.

${ }^{14}$ Yan, Q, Toghiani, H., Causey, H., "Steady State and Dynamic Performance of Proton Exchange Membrane Fuel Cells (PEMFCs) Under Various Operating Conditions and Load Changes," Journal of Power Sources, Vol. 161, No. 1, October 2006, pp. 492-502.

${ }^{15}$ Gee, M. K., "Cost and Performance Enhancements for a PEM Fuel Cell Turbocompressor," DOE Hydrogen Program Review, May 25, 2005; see also Ordonez, G., Gee, M. K., Liu, C., "Air, Water and Thermal Management for PEM Fuel Cell Systems," Fuel Cell Seminar, 2004, San Antonio, TX, November 2004.

${ }^{16}$ Larminie, J. and Lowry, J., Electric Vehicle Technology Explained, John Wiley \& Sons, Ltd., West Sussex, England, 2003.

${ }^{17}$ Warner, M., The Electric Vehicle Conversion Handbook, Penguin Group, New York, 2011.

${ }^{18}$ Chen, M. and Rincon-Mora, G. A., "Accurate Electrical Battery Model Capable of Predicting Runtime and $I-V$ Performance," IEEE Transactions on Energy Conversion, Vol. 21, No. 2, June 2006, pp. 504-511.

${ }^{19}$ Schiferl, R., Flory, A., Livoti, W.C., Umans, S.D., "High-Temperature Superconducting Synchronous Motors: Economic Issues for Industrial Applications," IEEE Transactions on Industry Applications, Vol. 44, No. 5, Sept.-Oct. 2008, pp. $1376-1384$.

${ }^{20}$ Turney, G. E., Luidens, R. W., Uherka, K. and Hull, J., "Aeronautical Applications of High-Temperature Superconductors," NASA TM 102311, 1989; also Paper AIAA-89-2142, Aircraft Design, Systems and Operations Conference, Seattle, July 31-Aug 2, 1989.

${ }^{21}$ Luongo, C. A., Masson, P. J., Nam, T., Mavris, D., Kim, H. D., Brown, G. V., Waters, M. and Hall, D., "Next Generation More-Electric Aircraft: A Potential Application for HTS Superconductors," IEEE Transactions on Applied Superconductivity, Vol. 19, No. 3, June 2009, pp. 1055-1068.

${ }^{22}$ Prouty, R. W., Helicopter Performance, Stability, and Control, Krieger Publishing Company, Malabar, FL, 2005.

${ }^{23}$ Rosen, K. M., "A Prospective: The Importance of Propulsion Technology to the Development of Helicopter Systems with a Vision for the Future, The 27th Alexander A. Nikolsky Lecture," Journal of the American Helicopter Society, Vol. 53, No. 4, October 2008, pp. 307-337. 